\title{
Inositol 1,4,5-Trisphosphate and Ryanodine Receptor Distributions and Patterns of Acetylcholine- and Caffeine-Induced Calcium Release in Cultured Mouse Hippocampal Neurons
}

\author{
Kathryn J. Seymour-Laurent and Michael E. Barish \\ Division of Neurosciences, Beckman Research Institute of the City of Hope, Duarte, California 91010
}

The distributions of inositol 1,4,5-trisphosphate and ryanodine receptors (Ins $P_{3} R$ and $R y R$ ) and the patterns of increase in intracellular calcium ion concentration $\left(\left[\mathrm{Ca}^{2+}\right]_{i}\right)$ elicited by their activation were compared in cultured hippocampal neurons. Ins $\mathrm{P}_{3} \mathrm{R}$ and $\mathrm{RyR}$ were labeled using specific antibodies and formed small aggregations in the somata and dendrites of pyramidally shaped neurons. Both receptors were densest in somata. In dendrites the Ins $P_{3} R$ and $R y R$ were not distributed homogeneously; Ins $P_{3} R$ was found in all regions, while $R y R$ was least dense in fine processes. Increases in $\left[\mathrm{Ca}^{2+}\right]_{i}$ elicited by acetylcholine (to activate Ins $_{3}$ receptors via muscarinic receptors) and caffeine (to stimulate ryanodine receptors) were measured in dendrites using $\mathrm{Ca}^{2+}$-sensitive fluorescent dyes and confocal microscopy. $\mathrm{Ca}^{2+}$ responses to acetylcholine were transient and observed in proximal and distal dendritic regions. In contrast, caffeine-induced responses were sustained and restricted to proximal dendrites. Thus the patterns of calcium release in fine dendrites mirrored the distributions of $\operatorname{Ins} P_{3} R$ and $R y R$. Calcium responses to both acetylcholine and caffeine were observed in the absence of external calcium and thus were dependent on $\mathrm{Ca}^{2+}$ release. $\mathrm{Ca}^{2+}$ responses showed localized fluctuations and variations in response delay times. Sequential activation of Ins $P_{3} R$ and $R y R$ in somata resulted in mutual occlusion of $\mathrm{Ca}^{2+}$ release. The existence of Ins $\mathrm{P}_{3}$-gated and $\mathrm{Ca}^{2+}$-induced $\mathrm{Ca}^{2+}$ release as spatially distinct, but mutually interacting, mechanisms may be important in the generation of oscillations and propagating $\mathrm{Ca}^{2+}$ waves in somata and dendrites of hippocampal neurons.

[Key words: antibody, RyR, Ins $P_{3} R$, Calcium Green-1, Fura-2, calcium, confocal microscopy, video microscopy, intracellular $\mathrm{Ca}^{2+}$ regulation]

Ionic calcium $\left(\mathrm{Ca}^{2+}\right)$ plays a central role in many neuronal processes including electrogenesis, synaptic transmission and plasticity, embryonic growth and differentiation, and activity-

\footnotetext{
Received July 5, 1994; revised Sept. 13, 1994; accepted Oct. 3, 1994.

We are grateful for gifts of antibodies from A. Sharp and S. Snyder (against Ins $P_{3}$ receptor) and $P$. McPherson and $K$. Campbell (against ryanodine receptor). We thank S. Hestrin, G. Laurent, and P. Steinbach for helpful comments on a previous version of the manuscript. This research was supported by a grant from the Norman and Sadie Lee Foundation and an Advanced Research Fellowship from the American Heart Association to K.J.S-L. M.E.B. was an Established Investigator of the American Heart Association during the execution of these experiments.

Correspondence should be addressed to Kathryn J. Seymour-Laurent at the above address.

Copyright $₫ 1995$ Society for Neuroscience $\quad 0270-6474 / 95 / 152592-17 \$ 05.00 / 0$
}

dependent gene expression (Kennedy, 1989). To function normally, neurons must coordinate the activation of $\mathrm{Ca}^{2+}$-dependent pathways while avoiding interference between $\mathrm{Ca}^{2+}$ signals. It might be expected, therefore, that neurons spatially and temporally compartmentalize the $\mathrm{Ca}^{2+}$ moving between the surface membrane, internal stores, and intracellular targets. Litthe is known about how this may occur.

The spatial and temporal distribution of $\left[\mathrm{Ca}^{2+}\right]_{i}$ increase after excitation will depend on many factors including the location and density of ion channels and neurotransmitter receptors, the distribution and avidity of $\mathrm{Ca}^{2+}$-binding proteins, and the arrangement of internal membrane-limited $\mathrm{Ca}^{2+}$ stores bearing sequestration pumps and release channels (Blaustein, 1988; Tsien and Tsien, 1990; Miller, 1991; Henzi and MacDermott, 1992). Hippocampal neurons exhibit at least two pharmacologically and molecularly defined mechanisms by which $\mathrm{Ca}^{2+}$ may be released from intracellular compartments: activation of inositol 1,4,5-trisphosphate receptors (Berridge and Taylor, 1988) and activation of ryanodine receptors (Thayer et al., 1988; Burgoyne et al., 1989). Interactions between these two mechanisms of $\mathrm{Ca}^{2+}$ release will influence the dynamic behavior of cytoplasmic $\mathrm{Ca}^{2+}$ signals in neurons. It is important, therefore, to understand the distributions and densities of intracellular $\mathrm{Ca}^{2+}$ release channels in different neuronal regions and the $\mathrm{Ca}^{2+}$ signals resulting from their activation.

InsP $\mathrm{P}_{3}$ receptors $\left(\operatorname{InsP}_{3} \mathrm{R}\right)$ (Furuichi et al., 1989; Mignery et al., 1989; Ross et al., 1989; Nakanishi et al., 1991; Volpe et al., 1991; Takei et al., 1992; Villa et al., 1992; Sharp et al., 1993a) and ryanodine receptors (RyR) (Ellisman et al., 1990; Padua et al., 1991; Sah et al., 1993) are both present in the mammalian brain. Although both receptors coexist in many neurons, their distributions differ between cerebellar Purkinje and hippocampal pyramidal neurons (Walton et al., 1991; Martone et al., 1993; Sharp et al., 1993b). In Purkinje cells, Ins $P_{3} R$ were found in spines and dendritic shafts and RyR were restricted to the shafts only (Walton et al., 1991), while the reverse was found in hippocampal neurons (Sharp et al., 1993b). However, the distributions of each receptor within single neurons have not been intensively investigated.

Ins $\mathrm{P}_{3} \mathrm{R}$ and $\mathrm{RyR}$ have both been localized to the endoplasmic reticulum (ER) (Ross et al., 1989; Ellisman et al., 1990; Walton et al., 1991; Villa et al., 1992). The highly interconnected ER of ncurons (Martone et al., 1994) appears to be responsible for the uptake, storage, and release of intracellular calcium (Miller, 1991; Henzi and MacDermott, 1992). The different distributions of Ins $\mathrm{P}_{3} \mathrm{R}$ and $\mathrm{RyR}$ in dendritic shafts and spines suggest that portions of the ER may be specialized for interaction with 
specific $\mathrm{Ca}^{2+}$ release channels, and therefore the increases in $\left[\mathrm{Ca}^{2+}\right]_{i}$ resulting from activation of $\mathrm{Ins} \mathrm{P}_{3} \mathrm{R}$ and $\mathrm{RyR}$ may differ spatially and temporally. This possibility has not been investigated in central neurons, despite physiological evidence indicating compartmentalization of $\mathrm{Ca}^{2+}$ signals between spines and dendritic shafts (Guthrie et al., 1991; Müller and Connor, 1991) and observations of spatially different patterns of $\mathrm{Ca}^{2+}$ release after stimulation of $\operatorname{InsP}_{3} R$ and $R y R$ in chromaffin cells and dorsal root ganglion neurons (Thayer et al., 1988; Burgoyne et al., 1989).

We describe here nonuniform and nonoverlapping distributions of $\operatorname{InsP}_{3} \mathrm{R}$ and $\mathrm{RyR}$, spatial and temporal nonhomogeneities in the intracellular $\mathrm{Ca}^{2+}$ responses induced by their activation, and functional interactions between these two $\mathrm{Ca}^{2+}$ stores. Our observations suggest that $\mathrm{Ca}^{2+}$ release from intracellular stores, and interactions between the two classes of $\mathrm{Ca}^{2+}$ release channels, may participate in shaping and partitioning the activity-dependent cytoplasmic $\mathrm{Ca}^{2+}$ signals modulating cellular functions in hippocampal neurons.

\section{Materials and Methods}

\section{Cultures of mouse hippocampal neurons}

Timed pregnant Swiss-Webster mice were obtained from Simonsen. Dissociated cell cultures were prepared from embryos aged 14-16 d of development using procedures previously described (Wu and Barish, 1992). Cells were grown in chambers constructed of a $17 \mathrm{~mm}$ diameter Teflon O-ring glued to a $25 \mathrm{~mm}$ diameter coverslip using Sylgard 184 (Dow Corning). Coverslips were coated with $100 \mu \mathrm{g} / \mathrm{ml}$ poly D lysine for $1 \mathrm{hr}$, rinsed with sterile water, and further coated with $25 \mu \mathrm{l}$ of $12.5 \mu \mathrm{g} / \mathrm{ml}$ laminin in Hank's balanced salt solution (HBSS) for 2-3 hr. Cells were plated into these chambers to give a final densily of $50 \times 10^{3} \mathrm{cells} / \mathrm{cm}^{2}$. An antimitotic agent, fluorodeoxyuridine $(10 \mu \mathrm{M})$, was added to the cells after $24 \mathrm{hr}$ in culture.

Neurons were used for experiments after $3-7 \mathrm{~d}$ in culture. They were identified as pyramidal based on the presence of a triangular perikaryon with a prominent apical dendrite and shorter basilar dendrites (Banker and Cowan 1977, 1979; Kreigstein and Dichter, 1983). Processes were identified as dendritic based on their lengths, tapering diameter, and branching pattern (Dotti et al., 1988). Using standard whole-cell patch-recording techniques we have not observed formation of functional synapses in these young cultures.

\section{Immunocytochemistry}

Dissociated cell cultures were rinsed three times with phosphate-buffered saline (PBS; pH 7.25) at room temperature and fixed with fresh $4 \%$ paraformaldehyde (in PBS) for $1 \mathrm{hr}$. Fixation and all subsequent steps were performed at $36^{\circ} \mathrm{C}$. After fixation the cells were rinsed with PBS, permeabilized with $0.1 \%$ Triton X-100 in PBS for $1 \mathrm{hr}$, and blocked by incubation in a solution of $2 \%$ BSA (Sigma ultrahigh avidity BSA, A-3424) and $0.2 \%$ Triton X-100 in PBS (PBS PSA $/ T X)$ for an additional hour. Dilutions of antibodies were made in $\mathrm{PBS}_{\mathrm{BSA} T \mathrm{~T}}$. Affinity-purified goat anti-InsP $P_{3} R$ (GT328) raised against purified rat cerebellar Ins $\mathrm{P}_{3}$ receptor (gift from Drs. S. H. Snyder and A. H. Sharp) and affinity-purified guinea pig anti-RyR (GP561) raised against purified rabbit brain ryanodine receptor (gift from Drs. K. P. Campbell and P. S. McPherson) were both used at 1:50 dilution.

In experiments involving reaction with a single antibody, cultures were incubated in primary antibody for $1 \mathrm{hr}$, then washed three times in $\mathrm{PBS}_{\mathrm{BSA} T \mathrm{TX}}(10 \mathrm{~min})$. The cells were then incubated for $1 \mathrm{hr}$ in the appropriate biotin-conjugated secondary antibody, either affinity-purified $\mathbf{F}\left(\mathrm{ab}^{\prime}\right)_{2}$ fragment goat anti-guinea pig IgG (Jackson Immunoresearch) or affinity-purified $\mathrm{F}\left(\mathrm{ab}^{\prime}\right)_{2}$ fragment rabbit anti-goat IgG, both at 1:200 dilution (Chemicon). After three washes in $\mathrm{PBS}_{\mathrm{BSA} / \mathrm{TX}}$, cells were incubated for $1 \mathrm{hr}$ in a 1:200 dilution of $\mathrm{Cy}$-3-conjugated streptavidin (Jackson Immunoresearch), washed three times, and mounted in SlowFade (Molecular Probes). Neurons were viewed using a Zeiss model 210 Confocal Laser Scanning Microscope (LSM) with a Zeiss $63 \times$ planachromat objective $(1.4 \mathrm{NA})$, Argon laser $(488 \mathrm{~nm})$ excitation, and a $520 \mathrm{~nm}$ long-pass barrier filter in front of the detec- tor. The thickness of the optical sections was estimated to be $0.25 \mu \mathrm{m}$ from information provided by the manufacturer (Carl Zeiss Inc.).

In double-labeling experiments, cells were fixed, washed, and incubated in anti-InsP $\mathrm{P}_{3} \mathrm{R}$ and anti-RyR antibody solutions $(1: 50 ; 1 \mathrm{hr}$ at $\left.36^{\circ} \mathrm{C}\right)$ as described above. The cells were then washed in $\mathrm{PBS}_{\mathrm{BSA} / \mathrm{TX}}$, incubated in 1:100 dilution Cy-3-conjugated rabbit anti-goat IgG (Jackson Immunoresearch; $1 \mathrm{hr}$ ), washed three times in $\mathrm{PBS}_{\mathrm{BSA} / \mathrm{TX}}$, incubated in 1:200 dilution goat anti-guinea pig biotinylated IgG (Jackson Immunoresearch; $1 \mathrm{hr}$ ), washed, incubated in 1:200 DTAFconjugated streptavidin (Jackson Immunoresearch; $1 \mathrm{hr}$ ), washed, and mounted in Slowfade. Neurons were viewed on the Zeiss LSM. Images using DTAF-conjugated antibodies were collected using heliumneon laser excitation at $543 \mathrm{~nm}$ and an emission filter with a bandpass at 522-535 $\mathrm{nm}$. Images using Cy-3-conjugated antibodies were collected using argon laser excitation at $488 \mathrm{~nm}$ and an emission filter with a bandpass at $610-660 \mathrm{~nm}$. We confirmed that these combinations of laser excitation wavelengths and bandpass emission filters yielded complete separation of red and green channels at the gain and offset levels employed. We also confirmed that the $2^{\circ}$ and $3^{\circ}$ antibodies did not give measurable nonspecific binding under the staining conditions employed.

Images acquired on the LSM were stored as PIC files (proprietary Zeiss format), translated to TIFF format using IMAGEFILE (R. Fetter, Department of Molecular and Cell Biology, University of California, Berkeley), and manipulated and analyzed using OPTIMAS (BioScan) and PHOTOSTYLER (Aldus) software.

\section{Measurement of intracellular $\mathrm{Ca}^{2+}$ concentrations}

Solutions. During experiments cells were continually perfused with a solution based on HBSS containing $137 \mathrm{~mm} \mathrm{NaCl}, 5.4 \mathrm{~mm} \mathrm{KCl}, 1.8$ $\mathrm{mM} \mathrm{CaCl}_{2}, 4.2 \mathrm{~mm} \mathrm{NaHCO}$, and $10 \mathrm{~mm}$ HEPES, at $\mathrm{pH} 7.25$. The perfusing solution also contained $0.3 \mu \mathrm{M}$ glutamate and $10 \mu \mathrm{M}$ glycine to activate $\mathrm{Ca}^{2+}$-permeant NMDA channels and replenish the intracellular $\mathrm{Ca}^{2+}$ stores between drug applications (Tsai and Barish, unpublished observations). When multiple responses were required we allowed $\mathrm{Ca}^{2+}$ release mechanisms to recover for 3-5 min between stimulations (Tsai and Barish, unpublished observations). $\mathrm{Ca}^{2+}$-free solutions were prepared by omitting $\mathrm{Ca}^{2+}$ salts; EGTA was not added. Solutions containing acetylcholine, caffeine, or ryanodine (Calbiochem) were made fresh each day. All chemicals were obtained from Sigma unless stated otherwise.

Loading with $\mathrm{Ca}^{2+}$-sensitive dyes. Cultured cells were loaded with Calcium green-1/AM or Fura-2/AM (both from Molecular Probes) in a $\mathrm{Mg}^{2+}$-free HBSS-based solution containing $1.8 \mathrm{mM} \mathrm{CaCl}_{2}$ and 25 mM HEPES using standard techniques. Stock solutions of Calcium green/AM or Fura-2/AM (1 mM) were prepared in dry DMSO. Each milliliter of loading solution contained $10 \mu \mathrm{l}$ of Calcium green/AM or Fura-2/AM stock, $10 \mu 1$ of $10 \%$ Pluronic F-127 aqueous solution, and $20 \mu \mathrm{l}$ of DMSO. Cells were incubated in the loading solution for $1 \mathrm{hr}$ at $36^{\circ} \mathrm{C}$, washed with $\mathrm{Mg}^{2+}$-free HBSS, then held for at least 2 hr at room temperature to allow cleavage of the acetoxymethyl (AM) ester to occur.

Measurement of $\left[\mathrm{Ca}^{2+}\right]_{\mathrm{i}}$ using the Zeiss $L S M$. All images of dendrites were acquired with the Zeiss LSM. Cells were loaded with Calcium green as described above. Cells in their coverslip chambers were mounted on the microscope stage and were continually perfused with $\mathrm{Mg}^{2+}$-free $\mathrm{Ca}^{2+}$-containing HBSS-based solution. Transmitters and drugs were applied to the cell region being imaged using a puffer pipette with a tip diameter of about $20 \mu \mathrm{m}$ placed approximately 50 $\mu \mathrm{m}$ from the cell. Dendrites selected for study originated from pyramidally shaped neurons and were not growing on astroglial cells. This eliminated any contribution of glial responses to the neuronal signals analyzed.

LSM images were collected using a Zeiss $40 \times$ achroplan waterimmersion objective ( $0.75 \mathrm{NA})$, argon laser ( $488 \mathrm{~nm})$ excitation, and a $520 \mathrm{~nm}$ long-pass barrier filter. We adjusted the laser illumination intensity to give the highest possible spatial resolution consistent with maintenance of cell viability and absence of photodynamic damage.

Image format and data analysis. Images $(256 \times 256$ pixels $)$ spanning $40 \times 26 \mu \mathrm{m}$ at the image plane were collected using ZEISS IMAGE SERIES software and stored digitally. They were translated to TIFF format using IMAGEFILE and processed as described below using OPTIMAS (Biosean) image analysis software. Since Calcium Green is used at a single excitation wavelength, changes in $\left[\mathrm{Ca}^{2+}\right]_{i}$ were calculated as fluorescence intensity at a given time $(F)$ divided by fluo- 


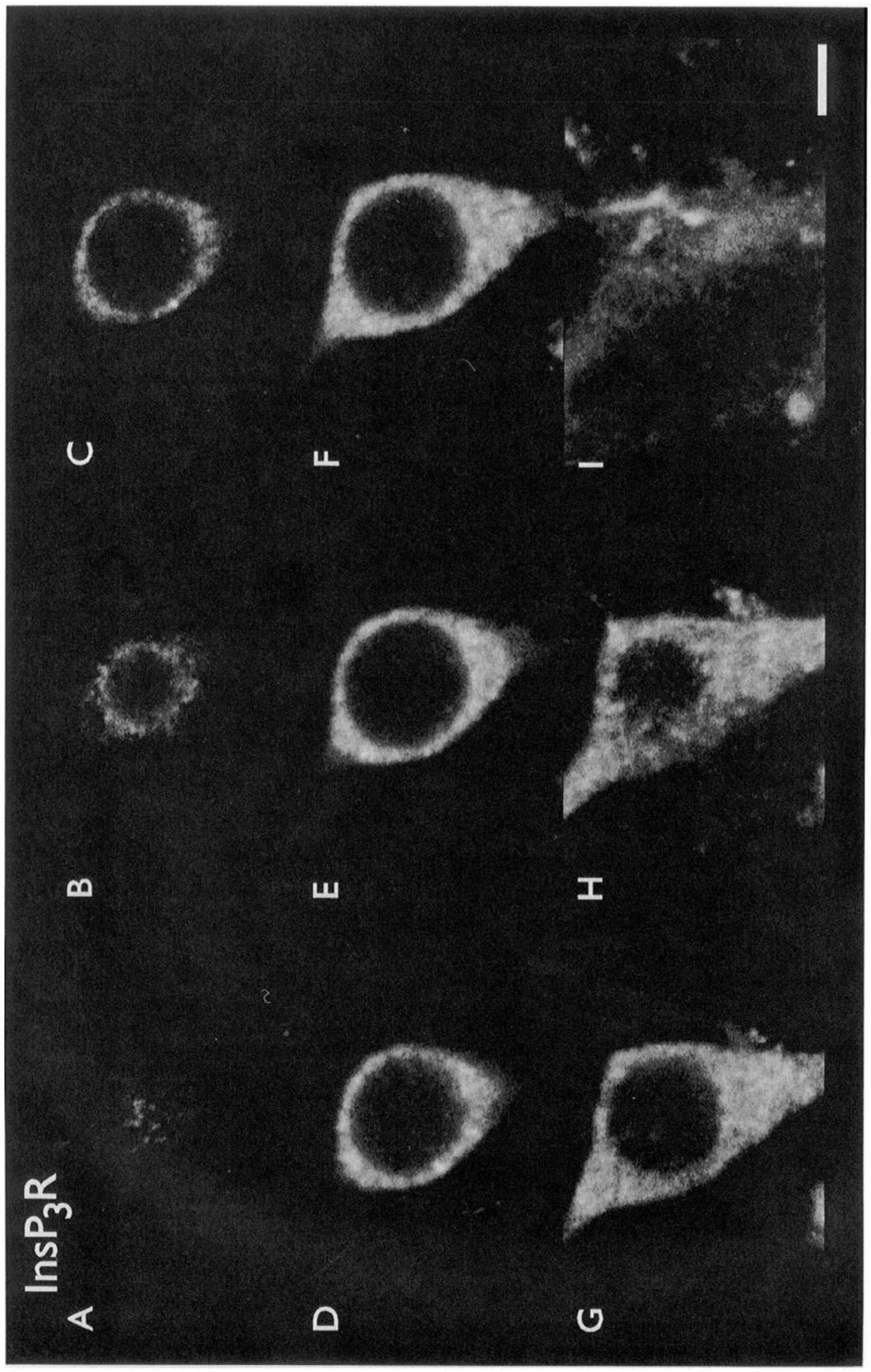

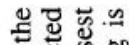

원은

: $8=$

至要

बहै

8 .

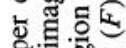

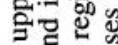

ฐ

이의

ำกำ

牙

कि.2

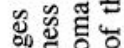

छ.

范

응 난

के एँ

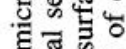

귤융

c원

ठㅀㅀㅀ

纯

记 도으

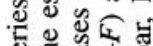

क्ष

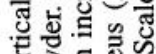

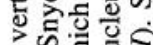

षं 3

i羊范

< ส

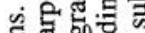

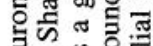

खंय

तु क् के

든젛․․

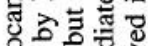

들 월

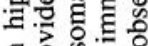

인

उ

중년.

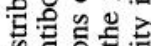

음 도을

추원

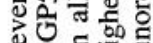

品

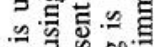

궁.

슬 을

บี

逭으

y

国

.

कि क्षे

의 드

㤩它芯

.

र

苛尔寻

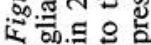



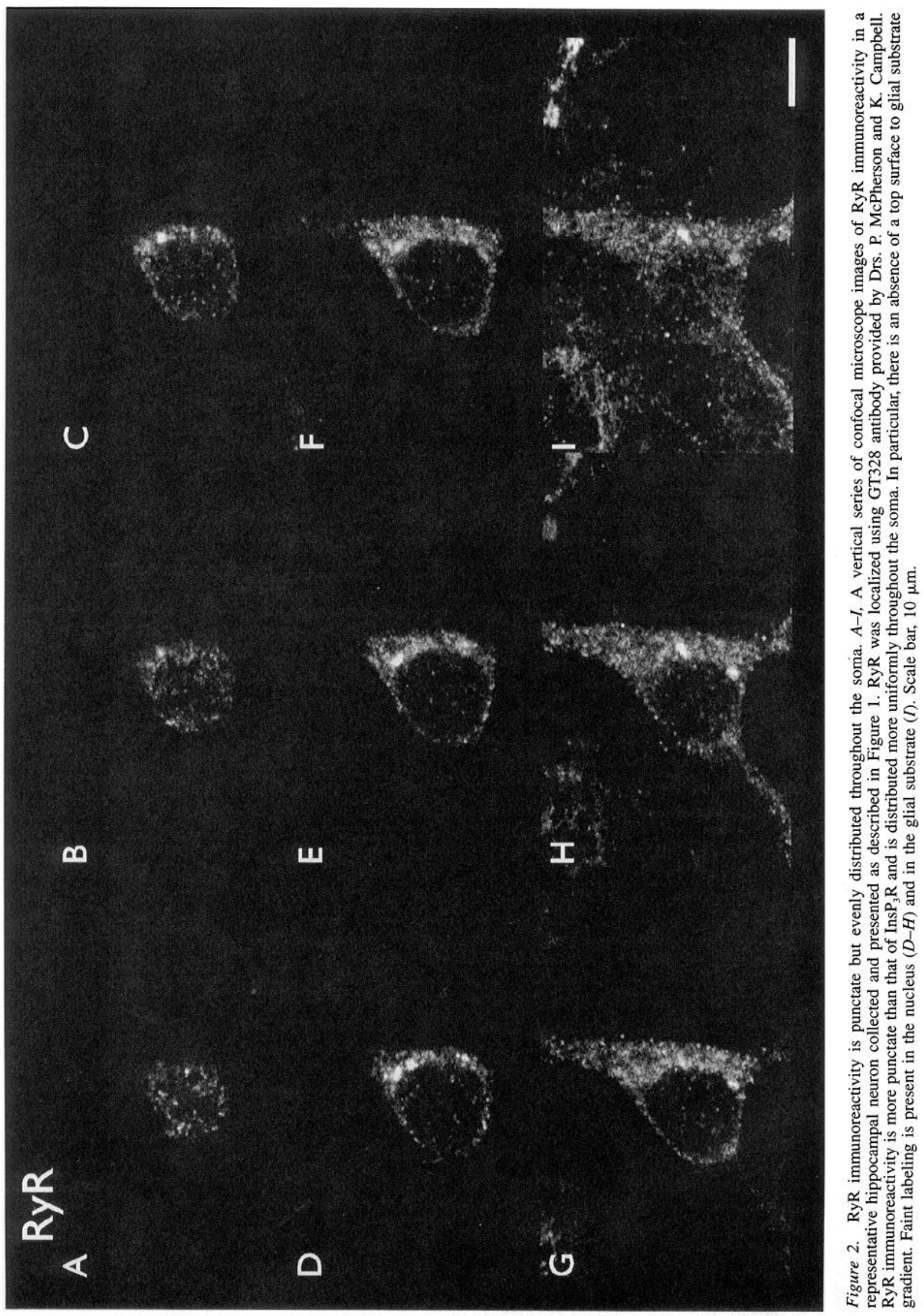

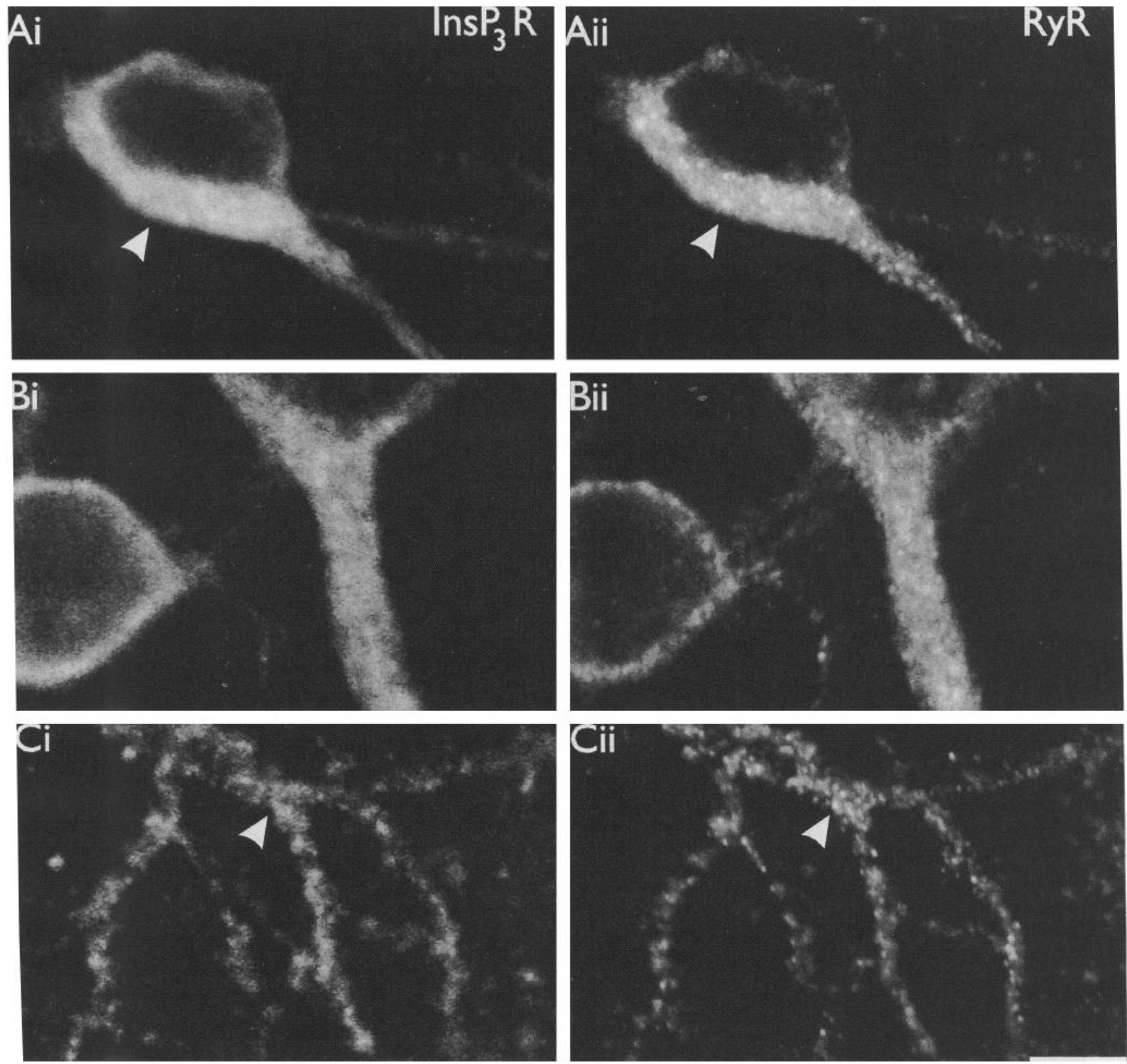

Figure 3. InsP $\mathrm{P}_{3} \mathrm{R}$ and $\mathrm{RyR}$ immunoreactivities have similar distributions in the soma and the apical process, but different distributions in the dendrites. Confocal microscope images of double-labeled hippocampal neurons immunostained for InsP ${ }_{3} \mathrm{R}(\mathrm{Ai}, \mathrm{Bi}, \mathrm{Ci})$ and RyR immunoreactivity (Aii, Bii, Cii) in soma ( $\mathrm{Ai}, \mathrm{Aii})$, and proximal $(\mathrm{Bi}, \mathrm{Bii})$ and distal $(\mathrm{Ci}, \mathrm{Cii})$ dendrites. $\mathrm{InsP}_{3} \mathrm{R}$ was localized using DTAF-conjugated secondary antibody and RyR was localized using biotin-conjugated secondary antibody followed by Cy-3-conjugated streptavidin (see Materials and Methods). The use of narrow bandpass barrier filters ensured no bleedthrough of fluorescence from one channel to the other. These gray-scale images can be compared directly as they were collected at the same gain and offset and processed with a single pass of a $3 \times 3$ pixel median filter. While both RyR and InsP ${ }_{3} \mathrm{R}$ immunoreactivity were always found in pyramidally shaped neurons, and the density of both was highest in regions of the soma near the emergence of a main dendrite, their distributions did not precisely overlap. In particular, the InsP $\mathrm{P}_{3} \mathrm{R}$ immunoreactivity was less aggregated than that for RyR (compare patterns of staining indicated by arrows in $A$ ), particularly in the distal dendrite (compare areas of staining near arrows in $C$ ). Images in $A-C$ were collected from different neurons. Scale bar: $A, 12 \mu \mathrm{m} ; B, 10.7 \mu \mathrm{m} ; C, 10 \mu \mathrm{m}$.

rescence at rest $\left(F_{0}\right)$. We compared images calculated as $F / F_{0}$ to images calculated as $\left(F-F_{0}\right) / F_{0}$, and concluded that the former procedure yielded the least noisy data. All the images were background subtracted and $F_{0}$ images were constructed as the average of four frames to minimize noise. $F / F_{0}$ was calculated for each frame on a pixel-by-pixel basis, and a median filter $(3 \times 3$ matrix $)$ was applied to each normalized image. To determine changes in $\left[\mathrm{Ca}^{2+}\right]_{i}$ in particular regions, areas of interest were outlined and the average $F / F_{0}$ value for each region (excluding black values) in each frame of a series was calculated in OPTIMAS and exported to an EXCEL (Microsoft) spreadsheet.

Two criteria had to be met before data were accepted. First, we tested each cell to insure that application of the perfusion medium alone did not increase $\left[\mathrm{Ca}^{2+}\right]_{i}$. Second, we tested for cell movement or changes in cell shape by masking, coloring, and overlaying the original (non-normalized) images. Any changes in cell outline were readily apparent, and if observed the cell was not considered further.

Measurement of $\left[\mathrm{Ca}^{2+}\right]_{\mathrm{i}}$ using quantitative video microscopy. All 


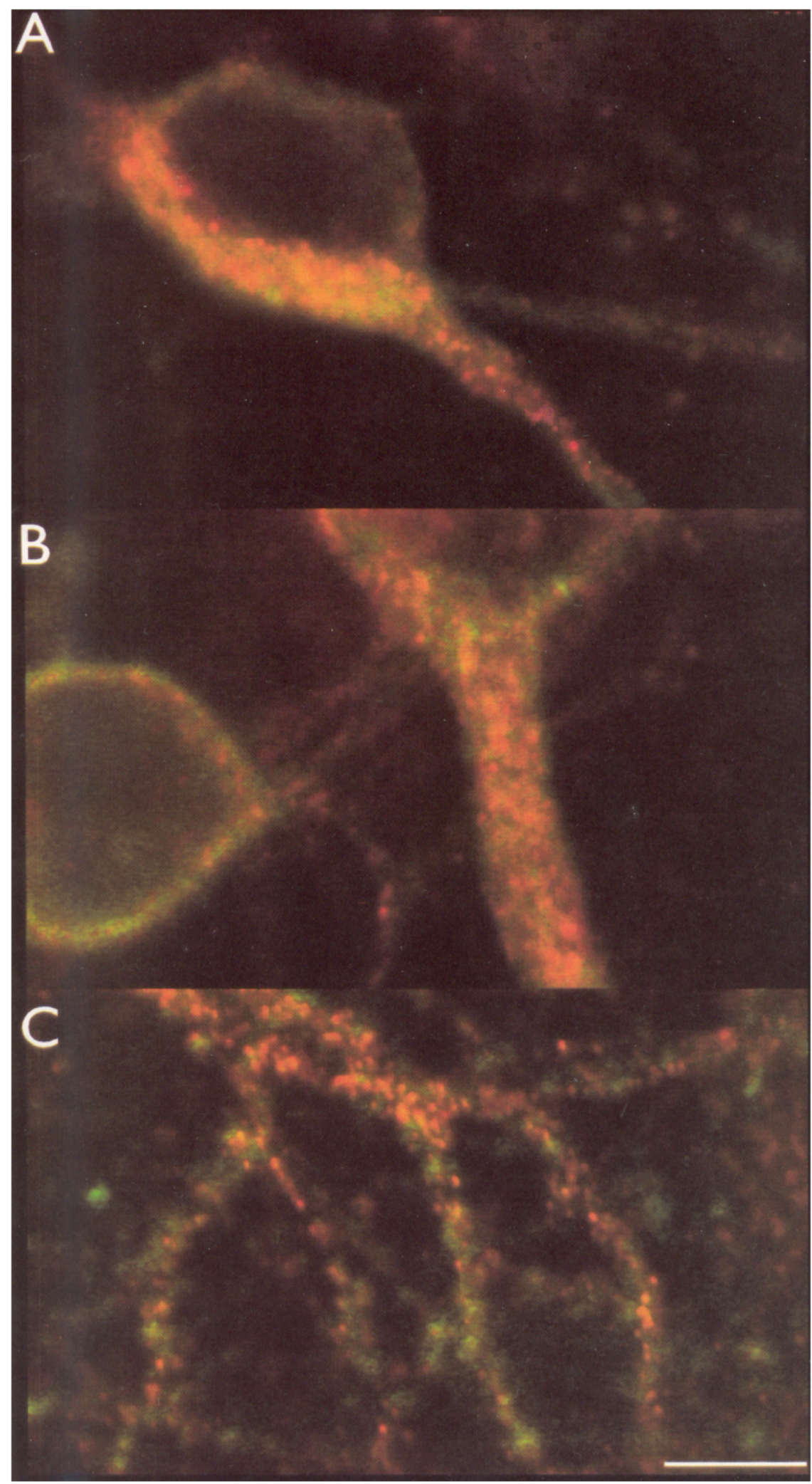

Figure 4. Regional differences in colocalization of InsP $\mathrm{P}_{3} \mathrm{R}$ and RyR immunoreactivities. In these combined confocal microscope images $\operatorname{InsP}_{3} \mathrm{R}$ immunoreactivity is green and RyR immunoreactivity is red. Immunostaining overlap appears as yellow. Multiple optical sections could be obtained from all regions including the dendrite because of the thin optical sections. The data collection and analysis for each pair of images was performed under identical conditions. Thus the intensity of the fluorescence in each image will reflect the density of $\mathrm{Ca}^{2+}$ release channels. We confirmed that the preparation did not shift between collections of the image pairs. The differences in red and green images were random in all directions and therefore were not due to systematic chromatic aberration. $A$, In the soma, high levels of InsP $\mathrm{P}_{3}$ and RyR immunoreactivity and substantial colocalization were observed near the base of the primary dendrite. Scale bar, $12 \mu \mathrm{m}$. $B$, In the apical process $\operatorname{Ins}_{3} \mathrm{R}$ and RyR immunoreactivities are more separate with less colocalization than in the soma. Scale bar, $10.7 \mu \mathrm{m}$. $C$, In the distal dendrites there is little overlap, and RyR immunostaining is more intense in the proximal regions of the dendrite (top of $C$ ), while Ins $\mathrm{P}_{3} \mathrm{R}$ immunoreactivity is more evenly distributed throughout the dendritic area. Scale bar, $10 \mu \mathrm{m}$.

images from somata were acquired using quantitative video microscopy. Cells were loaded with Fura-2/AM as described above. The cells in their coverslip chambers were mounted on the microscope stage and continually perfused with HBSS-based solution (see above). Test solutions were applied using a multibarreled puffer pipette with a tip diameter of about $500 \mu \mathrm{m}$ placed approximately $500 \mu \mathrm{m}$ from the cells being examined. One channel of the puffer pipette was always flowing; this procedure minimized fluid disturbance on changing solutions, and insured rapid exchange at the cell (estimated to be 250 $\mathrm{msec}$ ).

Measurements of $\left[\mathrm{Ca}^{2+}\right]_{i}$ were made using a camera-based image processing system (VideoProbe; ETM Systems) coupled to a Zeiss ICM-405 inverted microscope using standard procedures (Grynkiewicz et al., 1985). Images were collected using an Olympus $40 \times \mathrm{UV}$ 
APO (NA 1.4) objective and an intensified CCD camera (Hamamatsu). Neurons were illuminated using a $75 \mathrm{~W}$ xenon bulb and a computercontrolled filter changer in the excitation path (Lambda-10; Sutter Instruments). Fluorescence emission at $510 \mathrm{~nm}$ (bandwidth $40 \mathrm{~nm}$ ) was measured using excitation at 350 and $380 \mathrm{~nm}$ (bandwidths 10 and 13 $\mathrm{nm}$ ) and a dichroic mirror at $400 \mathrm{~nm}$. $\left[\mathrm{Ca}^{2+}\right]_{i}$ was calculated from the ratio $(R)$ of fluorescence emissions after background subtraction $(F)$ $\left(F_{350} / F_{380}\right)$, according to the relation (Grynkiewicz et al., 1985)

$$
\left[\mathrm{Ca}^{2+}\right]_{i}=K_{d}\left(F_{380, \min } / F_{380, \text { max }}\right)\left[\left(R-R_{\min }\right) /\left(R_{\max }-R\right)\right]
$$

The $K_{d}$ for Fura-2 at room temperature was taken to be 135 nM (Grynkiewicz et al., 1985) and the min and $\max$ fluorescence values were obtained during calibration experiments with minimum and saturating concentrations of internal calcium. Minimum $\left[\mathrm{Ca}^{2+}\right]_{i}$ was measured after incubation of cclls in a $\mathrm{Ca}^{2+}$-frce solution containing $10 \mu \mathrm{M}$ 4-bromo A-23187 (Molecular Probes) and $10 \mathrm{~mm}$ EGTA for $30 \mathrm{~min}$. Maximum $\left[\mathrm{Ca}^{2+}\right]_{i}$ values were obtained after incubating the same cells in a solution containing $10 \mu \mathrm{M} 4$-bromo A-23187 and $10 \mathrm{mM} \mathrm{Ca}^{2+}$.

\section{Results}

\section{The distributions of anti-Ins $P_{3} R$ and anti-RyR}

\section{immunoreactivity}

Immunostaining and confocal microscopy techniques were employed to determine (1) if $\operatorname{Ins}_{3} \mathrm{R}$ and $\mathrm{Ry} R$ coexist in pyramidally shaped hippocampal neurons, and (2) to identify their patterns of staining and areas of potential overlap within soma and dendritic regions. The data presented here are representative of eight and 10 neurons studied in multiple optical sections through the soma and reacted with a single antibody against $\mathrm{InsP}_{3} \mathrm{R}$ or RyR, respectively, 71 and 67 neurons studied in single optical sections and reacted with either one or the other antibody, and 37 neurons studied in single optical sections and reacted with both antibodies. Data for the apical processes are representative of four and three processes studied in multiple optical sections and reacted with a single antibody against Ins $P_{3} R$ or RyR, respectively, 26 and 31 neurons studied in single optical sections and reacted with either one or the other antibody, and 17 neurons studied in single optical sections and reacted with both antibodies. The data presented for dendrites of thickness $1 \mu \mathrm{m}$ or less are representative of 19 and 24 dendrites studied in single optical sections and reacted with either one or the other antibody, and 12 dendrites studied in single optical sections and reacted with both antibodies. Excessive photodynamic bleaching precluded obtaining multiple optical sections from doubly stained neurons.

To determine the distribution of $\mathrm{Ca}^{2+}$ release channels within the somata of neurons, the cells were immunostained for Ins $\mathrm{P}_{3} \mathrm{R}$ (Fig. 1) and RyR (Fig. 2), and a series of optical sections were collected at $2 \mu \mathrm{m}$ intervals through the pyramidally shaped cell bodies. Ins $\mathrm{P}_{3} \mathrm{R}$ immunoreactivity was found throughout somata (Fig. 1), but had a nonuniform distribution that was particularly intense in regions close to the nucleus (Fig. $1 D-F$ ). In addition, a gradient of immunoreactivity was observed through the cell body, with the highest receptor density in the cytoplasmic region next to the glial substrate on which the cells were growing (Fig. 1). RyR immunoreactivity was more punctate and was concentrated in the apical region of the neuron (Fig. $2 E-G$ ). There was no evidence that RyR immunorcactivity was polarized relative to the glial surface.

In doubly labeled cells, the distributions of anti-Ins $\mathrm{P}_{3} \mathrm{R}$ and anti-RyR immunoreactivity were similar but not identical (Figs. $3,4)$. Comparison of gray-scale images that were collected and processed identically (Fig. 3) shows that RyR immunoreactivity is more highly aggregated than that of $\operatorname{InsP}_{3} \mathrm{R}$ (arrows in Fig. 3). The colored images (in which RyR immunoreactivity is red, $\operatorname{InsP}_{3} \mathrm{R}$ is green, and regions of overlap are yellow) emphasize the close proximity of the aggregations of intense Ins $\mathrm{P}_{3} \mathrm{R}$ and $\mathrm{RyR}$ immunoreactivity in somata and proximal dendrites (Fig. 4A,B). Some aggregations of $\operatorname{Ins}_{3} \mathrm{R}$ and RyR were in close proximity, while others could be resolved independently (Fig. 4C). RyR tended to be restricted mainly to larger diameter dendrites, while $\operatorname{Ins}_{3} \mathrm{R}$ extended throughout all processes (Fig. $4 C$ ). In fine processes the density of both $\mathrm{Ca}^{2+}$ release channels was lower than in other neuronal regions (Fig. 4C). Release channel density can be estimated from these images because the optical section thickness was identical for all regions of the cell, and therefore each image shows fluorescence from the same volume.

In summary, while $\operatorname{Ins}_{3} \mathrm{R}$ and $\mathrm{RyR}$ immunoreactivity was found throughout neurons, the receptors differed in their extent of aggregation. Further, the spatial distributions of the two $\mathrm{Ca}^{2+}$ release channels are not the same in dendrites, although they may be in close proximity to one another in other regions. These observations are consistent with the idea that they exist on different sections of ER, particularly in fine dendrites.

\section{The patterns of intracellular $\mathrm{Ca}^{2+}$ release}

These experiments were designed to determine the spatial and temporal distribution of changes in $\left[\mathrm{Ca}^{2+}\right]_{i}$ after release of $\mathrm{Ca}^{2+}$ from intracellular stores in dendrites in response to two different stimuli. Acetylcholine was applied externally to activate muscarinic receptors (M1 is the dominant subtype; Levey, 1993) and stimulate production of InsP $_{3}$ and intracellular $\mathrm{Ca}^{2+}$ release (Berridge et al., 1983; Kudo et al., 1988). Responses to acetylcholine were completely abolished with simultancous application of $2 \mu \mathrm{M}$ atropine (data not shown). Caffeine was used to activate ryanodine receptor channels (Murphy and Miller, 1989; Tsai and Barish, 1990, 1991, unpublished observations; Uneyama et al., 1993) underlying $\mathrm{Ca}^{2+}$-induced $\mathrm{Ca}^{2+}$ release. Cyclic ADP-ribose may be an endogenous activator of these ryanodine receptor channels (White et al., 1993; Buck et al., 1994). Not all cells responded to acetylcholine, although the proportion that did increased with culture age; after $3 \mathrm{~d}$ in culture about $25 \%$ of neurons responded to acetylcholine, and after $7 \mathrm{~d}$ more than $60 \%$ responded $(n=$ more than 100 cells; data not shown). The number of neurons that responded to caffeine also increased with culture age, from about $20 \%$ after $3 \mathrm{~d}$ to at least $50 \%$ after $7 \mathrm{~d}(n=$ more than 100 cells; data not shown; see also Tsai and Barish, unpublished observations). Changes in $\left[\mathrm{Ca}^{2+}\right]_{i}$ in dendrites were recorded using a confocal LSM to obtain the highest spatial resolution. Using this image collection system, up to three separate responses could be recorded from processes before bleaching and photodynamic damage became excessive. Experiments were performed with $\mathrm{Ca}^{2+}$ in the external solution to allow replenishment of internal stores between trials.

We assumed that intracellular concentrations of caffeine and InsP $_{3}$ were elevated uniformly within the portions of neurons examined because both acetylcholine and caffeine were applied rapidly over the entire ncuron (sec Matcrials and Methods), and because within the limited fields examined $(40 \times 26 \mu \mathrm{m})$ muscarinic acetylcholine receptors appear to be distributed relatively uniformly (Levey et al., 1991). Thus we have taken the increases in $\left[\mathrm{Ca}^{2+}\right]_{i}$ observed to reflect the distributions of Ins $\mathrm{P}_{3} \mathrm{R}$ and $\mathrm{RyR}$. On a larger scale of the whole neuron, however, variations in muscarinic acetylcholine receptor density as 
well as nonhomogeneities in the distributions of $\mathrm{Ca}^{2+}$-binding proteins will also shape intracellular $\mathrm{Ca}^{2+}$ signals.

Data collection methods and analysis techniques for the $\mathrm{Ca}^{2+}$ responses to acetylcholine and caffeine are described in $\mathrm{Ma}$ terials and Methods. We observed that prior to stimulation normalized fluorescence was maintained at a uniform level over the image field (see images on left in Figs. 5Ai-Ci, 6Ai-Ci). Differences in $\mathrm{Ca}^{2+}$ responses after stimulation were not due to dendrite thickness varying in the field of view, as the optical section collected was constant and less than the diameter of the smallest process, and data are presented as normalized to initial fluorescence intensity. The examples presented below are representative of 20 and 22 neurons responsive to acetylcholine and caffeine, respectively.

$\mathrm{Ca}^{2+}$ responses to acetylcholine. Images and analyses of the $\mathrm{Ca}^{2+}$ responses in dendrites in response to stimulation by acetylcholine are presented in Figure 5. The pscudocolored images show $F / F_{0}$ calculated on a pixel-by-pixel basis as described in Materials and Methods. Stimulation with acetylcholine (10 $\mu \mathrm{M})$ elicited transient increases in $\left[\mathrm{Ca}^{2+}\right]_{i}$ with a latency of about $2.5 \mathrm{sec}$. The responses reached a peak after $5-15 \mathrm{sec}$, and returned to baseline within about $25 \mathrm{sec}$ even in the continued presence of the agonist (images on right in Fig. 5Aii-Cii). Responses occurred in fine processes (Fig. $5 A, B$ ) as well as in thicker processes more proximal to the cell body (Fig. $5 C$ ). Within different dendrites we observed spatial and temporal variations in $\left[\mathrm{Ca}^{2+}\right]_{i}$ responses to acetylcholine. Spatially, the increase in $\left[\mathrm{Ca}^{2+}\right]_{i}$ may extend throughout all processes in the field of view (Fig. $5 A i$ ), show localized increases in $\left[\mathrm{Ca}^{2+}\right]_{i}$ or "hot spots" (Fig. 5Ai,Bi), or have increases restricted to only a portion of the image field (Fig. $5 \mathrm{Ci}$ ). Thus two regions with a large response could be separated by a nonresponsive region of the dendrite (red, blue, and yellow regions in Fig. $5 \mathrm{C}$ ). Temporally, some regions showed an increase in $\left[\mathrm{Ca}^{2+}\right]_{i}$ with a single peak response (Fig. 5A,C), while others exhibited small fluctuations after the peak response (for example the red region in Fig. $5 B$ ). Response latencies of regions in the same cell also varied (Fig. $5 C$ ). Further, some cells showed a second response $10-40 \mathrm{sec}$ after the first one (Figs. 5Bii, 7A). These patterns were seen with approximately equal frequency.

$\mathrm{Ca}^{2+}$ responses to caffeine. The changes in $\left[\mathrm{Ca}^{2+}\right]_{i}$ in dendrites elicited by caffeine $(10 \mathrm{mM})$ showed some consistent differences when compared with those induced with acetylcholine (Fig. 6). First, dendritic responses to caffeine were more sustained than those to acetylcholine. In the presence of caffeine, $\left[\mathrm{Ca}^{2+}\right]_{i}$ in dendrites usually required $2-4 \mathrm{~min}$ to return to resting levels (Fig. $6 A, B$ ), although a few processes showed slight recovery, but not to resting levels, after 20-25 sec (Fig. $6 C$ ). Second, localized increases in $\left[\mathrm{Ca}^{2+}\right]_{i}$, or "hot spots," were observed less often with caffeine than with acetylcholine (compare Figs. 5Aii-Cii, 6Aii-Cii). Third, increases in $\left[\mathrm{Ca}^{2+}\right]_{i}$ in response to caffeine were restricted to thicker processes and did not extend into fine ( $1 \mu \mathrm{m}$ or less diameter) dendrites (image on right in Fig. 6Ai, Ci). Other properties of caffeine-induced release were similar to those of acetylcholine-induced $\mathrm{Ca}^{2+}$ changes, including response latency, time to peak, and peak amplitude (compare graphs in Figs. 5-7).

There was considerable region-to-region variability in caffeine-induced $\mathrm{Ca}^{2+}$ responses. Regions within the same field could exhibit monotonic increases (green region in Fig. 6B), or small fluctuations about the peak (red regions in Fig. 6Aii,Bii), show different latencies of response (Fig. 6Aii,Bii) or times to peak (Fig. 6Bii), have different peak amplitudes (Fig. 6Bii, Cii), or not respond at all (Fig. 6Aii, Cii). Caffeineinduced $\mathrm{Ca}^{2+}$ release could occur in some regions while adjacent, and generally distal, regions could fail to show a $\mathrm{Ca}^{2+}$ increase (Fig. 6A,C). As with acetylcholine, these responses were seen with approximately the same frequency.

$\mathrm{Ca}^{2+}$ responses were occasionally observed to propagate along a dendrite. In the neuron illustrated in Figure $6 B$, an increase in $\mathrm{Ca}^{2+}$ appeared to move from right to left along the dendrite, as indicated by the increasing times to peak in the red and green, and the blue and yellow regions.

$\mathrm{Ca}^{2+}$ responses to acetylcholine and caffeine in the same dendrite. Dendrites were sequentially stimulated with both caffeine and acetylcholine to reveal potential differences in the patterns of $\mathrm{Ca}^{2+}$ release. Processes that responded to acetylcholine did not always respond to caffeine and vice versa. About $30 \%$ of cells that responded to one stimulus also responded to the other ( $n$ is greater than 40 ). The proportion of cells responding to both acetylcholine and caffeine increased with culture age, but this was not quantified. A total of 13 observations were made on dendrites responding to both acetylcholine and caffeine.

Two examples of dendrites that responded to both acetylcholine and caffeine are presented (Figs. 5A, 6A, 7). The order in which stimuli were presented did not affect the patterns of

\footnotetext{
Figure 5 (top). Acetylcholine-induced release of $\mathrm{Ca}^{2+}$ in dendrites is phasic and localized. $\mathrm{Ai}, \mathrm{Bi}$, and $\mathrm{Ci}$ are confocal microscope images of $\mathrm{Ca}{ }^{2+}$ release in three different representative neurons. The images shown are $F / F_{0}$ (see Image format and data analysis in Materials and Methods) where $\left[\mathrm{Ca}^{2+}\right]_{i}$ is indicated by color; warmer colors represent higher $\left[\mathrm{Ca}^{2+}\right]_{i}$, as shown in the color bar. Acetylcholine $(10 \mu \mathrm{M})$ was applied using a puffer pipette. The proximal dendrite is toward the top of the image in this and the following figures. The first image in each pair shows the dendrite at rest and the second shows the maximal response, which occurred after about $5 \mathrm{sec}$ for $\mathrm{Ai}$ and $\mathrm{Ci}$ and after about $15 \mathrm{sec}$ for $\mathrm{Bi}$. Changes in [Ca $\left.{ }^{2+}\right]_{i}$ were spatially nonuniform across the processes and could be restricted to small localized regions ( $A i$, $B i$ ). Regions may show different response latencies $(\mathrm{Aii}, \mathrm{Cii})$, and some regions were unresponsive $(\mathrm{Ci})$. Scale bar, $20 \mu \mathrm{m}$. Aii, Bii, and $\mathrm{Cii}$ are plots of average changes in $\left[\mathrm{Ca}^{2+}\right]_{i}$ for the regions indicated by the colored ovals in each resting image against time. The average $F / F_{0}$ values for each region were calculated as described in Materials and Methods. Acetylcholine caused a transient increase in $\left[\mathrm{Ca}^{2+}\right]_{i}$ that lasted about $10 \mathrm{sec}$. Frames were collected every 2.56 sec and acetylcholine was applied continuously beginning at the end of the fifth frame collection, as indicated by the solid line in each plot. Note that the time base in $C i i$ is different from $A i i$ and $B i i$.
}

Figure 6 (bottom). Caffeine-induced release of $\mathrm{Ca}^{2+}$ in dendrites is sustained and localized. $\mathrm{Ai}$, $\mathrm{Bi}$, and $\mathrm{Ci}$ are confocal microscope images showing $\mathrm{Ca}^{2+}$ release in three representative dendrites in response to $10 \mathrm{~mm}$ caffeine. Data collection, analysis, and presentation are as described for Figure 5. Caffeine-induced $\mathrm{Ca}^{2+}$ release tended to be restricted to larger dendritic regions. Scale bar, $20 \mu \mathrm{m}$. Aii, Bii, and Cii are plots of normalized fluorescence values in four regions of each dendritic field. Caffeine consistently induced a sustained increase in [Ca ${ }^{2+}$, for up to 65 sec in some regions. Some regions may not respond to caffeine (Aii, Cii). Bii shows propagation of a $\mathrm{Ca}^{2+}$ wave front along the dendrite; the red and green regions responded before the yellow and blue regions. Frames were collected every $2.56 \mathrm{sec}$ and caffeine was applied continuously beginning at the end of the fifth frame collection, as represented by the solid black line on the plots. Note that the time base in Cii is different from Aii and Bii. 

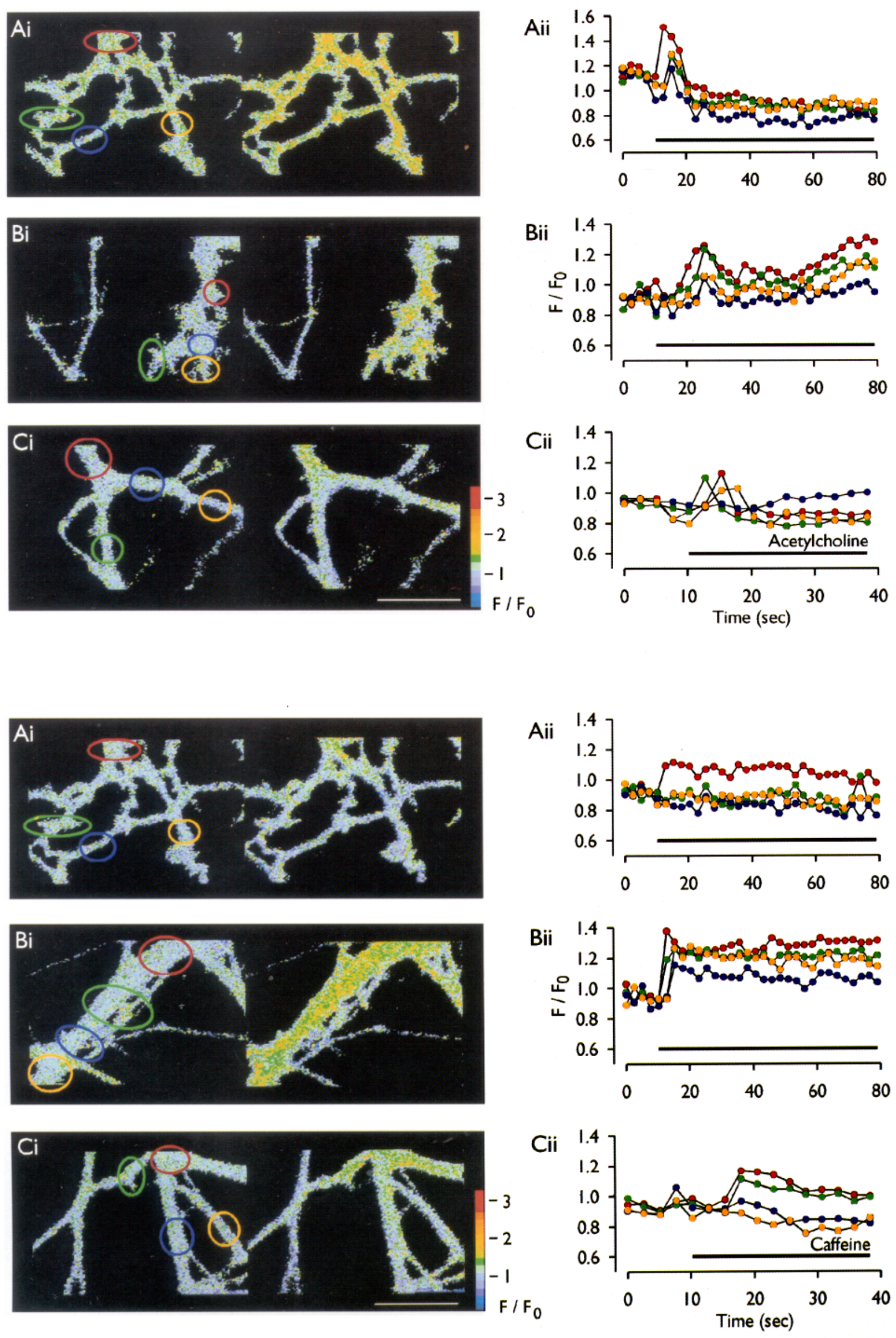
$\mathrm{Ai}$

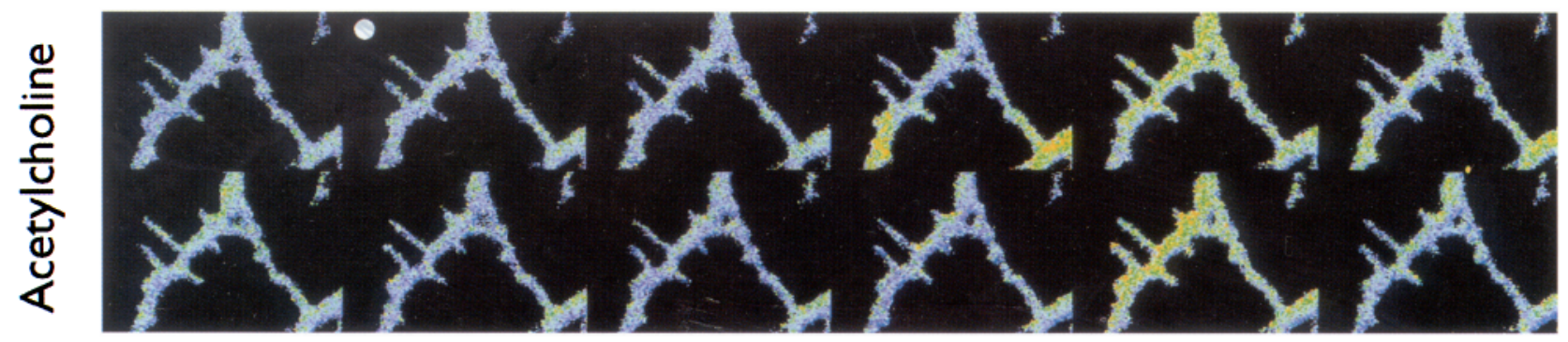

$\mathrm{Bi}$

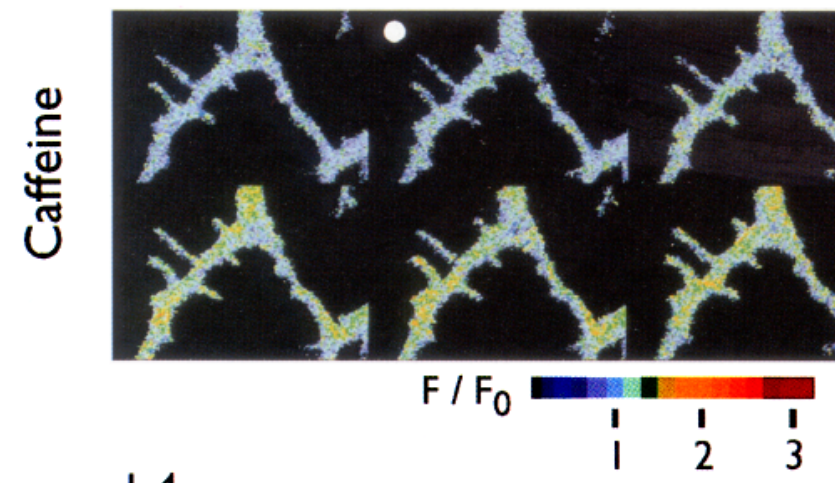

Aii

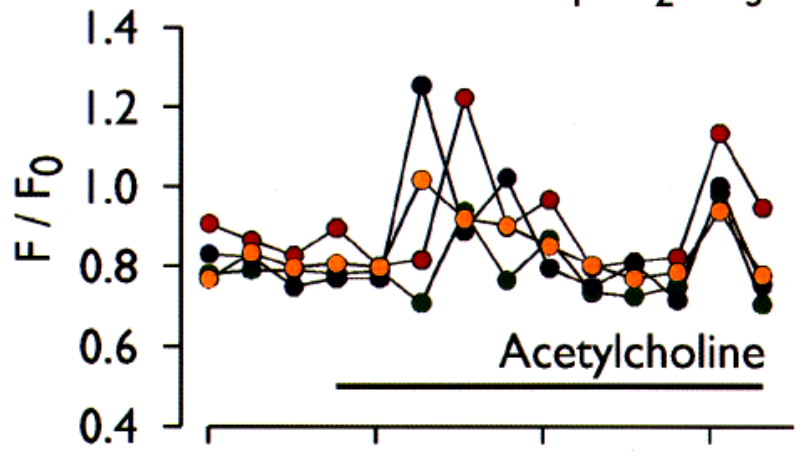

Bii

0

10

20

30

Time (sec)

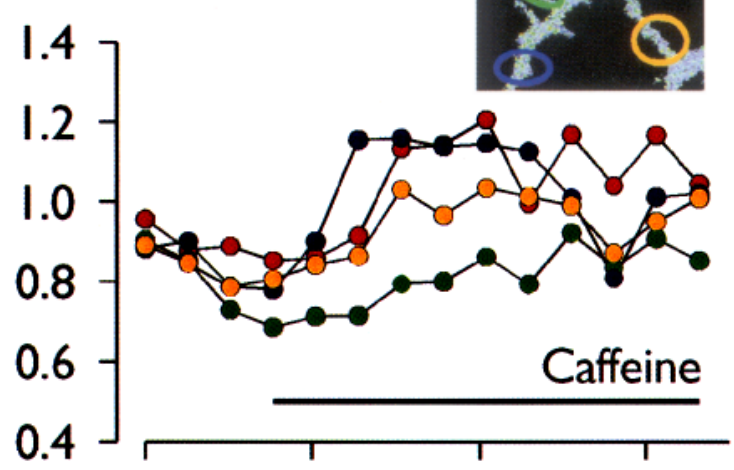

Figure 7. Acetylcholine-induced and caffeine-induced patterns of changes in $\left[\mathrm{Ca}^{2+}\right]_{i}$ may differ within the same dendrite. Ai is 12 consecutive normalized $\left(F / F_{0}\right)$ fluorescence confocal microscope images collected at $2.56 \mathrm{sec}$ intervals demonstrating $\left[\mathrm{Ca}^{2+}\right]_{i}$ changes in response to $10 \mu \mathrm{M}$ acetylcholine. The first image in each series shows $\left[\mathrm{Ca}^{2+}\right]_{i}$ at rest. The proximal region of the dendrite is toward the top of each image. The pseudocolor bar indicates the color representing the fluorescence values. Scale bar, $20 \mu \mathrm{m} . B i$ is 12 consecutive images of the same dendrite in $A i$ collected as above in response to $10 \mathrm{~mm}$ caffeine. The stimulus was continuously applied using a puffer pipette beginning in the frame marked with a white dot in the upper left corner. The dendrite was washed for $3 \mathrm{~min}$ between drug exposures to allow the [Ca $\left.{ }^{2+}\right]_{i}$ to return to resting levels (compare the two $\left[\mathrm{Ca}^{2+}\right]_{i}$ images at rest). Aii, Average normalized fluorescence values in the four regions indicated in the inset image on the right in response to acetylcholine plotted against time. The acetylcholine-induced $\mathrm{Ca}^{2+}$ increase was transient, and occurred with variable amplitude and latency. Bii is the average normalized fluorescence values in the same four regions as Aii in response to caffeine. The caffeine-induced $\mathrm{Ca}^{2+}$ response was more sustained, but also showed variable latency. The green region, which responded to acetylcholine, was less responsive to caffeine. Figures $5 A i$ and $6 A i$ were collected from the same dendrite and show that regions responding to acetylcholine did not necessarily respond to caffeine. Comparison of these images also indicates that caffeine responses were stronger in proximal regions while acetylcholine responses were distributed throughout the dendrite.

change in $\left[\mathrm{Ca}^{2+}\right]_{i}$; caffeine was presented first in Figures $5 \mathrm{~A}$ and $6 A$, while acetylcholine was presented first in Figure 7.

Within a given region the time between the application of each stimulus and the onset of the response could differ. For example, in Figure 7, Aii and Bii, the yellow region responded to caffeine at the same time as the red region, but one frame time $(2.6 \mathrm{sec})$ earlier to acetylcholine. Further, the acetylcholine- and caffeine-induced $\mathrm{Ca}^{2+}$ responses could be spatially distinct (Figs. 5A, 6A), although in some processes $\mathrm{Ca}^{2+}$ responses were in the same regions (Fig. 7). In general, $\mathrm{Ca}^{2+}$ responses to caffeine were restricted to thicker dendrites more proximal to the soma, while the $\mathrm{Ca}^{2+}$ responses to acetylcho- line extended into fine processes. Examples of this can be seen when comparing Figures $6 \mathrm{~A}$ and $5 \mathrm{~A}$, and in the $\mathrm{Ca}^{2+}$ response of the small side branch from the dendrite (green region in Fig. 7) which exhibited changes in $\left[\mathrm{Ca}^{2+}\right]_{i}$ in response to acetylcholine, but showed a much smaller response to caffeine.

While both stimuli could induce time-varying fluctuations in $\left[\mathrm{Ca}^{2+}\right]_{i}$, these had different spatial and temporal patterns within the same dendrite (Fig. 8). Following application of caffeine, $\left[\mathrm{Ca}^{2+}\right]_{i}$ initially increased in a localized portion of the distal dendrite $(-$ in Fig. $8 B)$. The region of high $\left[\mathrm{Ca}^{2+}\right]$ then spread throughout the dendrite and fluctuated around an elevated steady state. In contrast, acetylcholine-induced $\mathrm{Ca}^{2+}$ fluctua- 


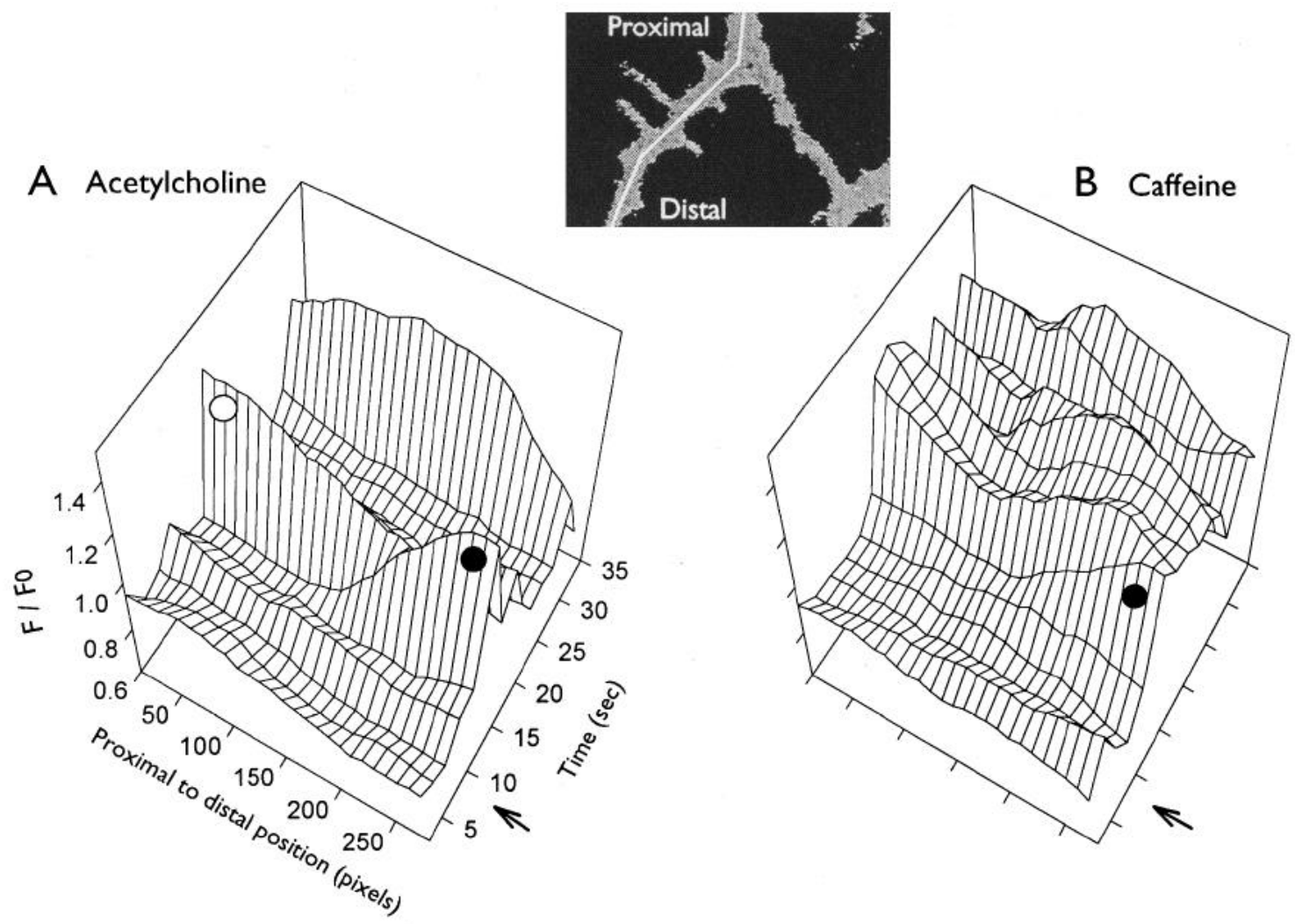

Figure 8. In response to acetylcholine and caffeine, regions of high $\left[\mathrm{Ca}^{2+}\right]_{i}$ may shift position along a dendrite with time. The images presented in Figure 7 were used in this analysis. The changes in $\left[\mathrm{Ca}^{2+}\right]_{i}$ in response to acetylcholine or caffeine were measured along the line shown in the

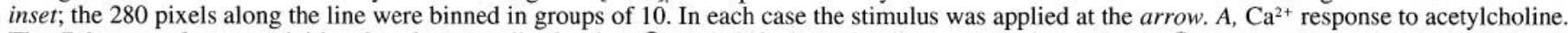
The $\mathrm{Ca}^{2+}$ wave front was initiated at the most distal point $(-)$ and shifted proximally over two frame times $(O) . B$, $\mathrm{Ca}^{2+}$ response to caffeine. The change in $\left[\mathrm{Ca}^{2+}\right]_{i}$ was initiated in the same proximal region as the response to acetylcholine, but showed small fluctuations in $\left[\mathrm{Ca}^{2+}\right]_{i}$ around the elevated steady state.

tions tended to be larger and more localized, with $\left[\mathrm{Ca}^{2+}\right]_{i}$ returning to resting levels before the initiation of the next cycle (Fig. 8A). The shift over time in the location of the $\mathrm{Ca}^{2+}$ peak may indicate the presence of a $\mathrm{Ca}^{2+}$ wave (Fig. 8A). Thus the initial $\mathrm{Ca}^{2+}$ response, the putative leading edge, started in the distal portion of the dendrite ( 1 in Fig. $8 A$ ) and by the next frame (2.6 sec later) had shifted proximally $(\bigcirc$ in Fig. $8 A$ ).

Fluctuating changes in $\left[\mathrm{Ca}^{2+}\right]_{i}$ in response to stimulation may be a common characteristic of hippocampal neurons. Fluctuations in $\left[\mathrm{Ca}^{2+}\right]_{i}$ similar to those presented in Figures 5-8 were observed in $50 \%$ (11 out of 22) of neurons responding to caffeine and $55 \%$ (11 out of 20 ) neurons responding to acetylcholine. Of the 13 neurons responding to both caffeine and acetylcholine, six displayed fluctuations in response to both stimuli and four showed single transient responses to both stimuli. Of the remaining three neurons, two showed fluctuations to acetylcholine only and one to caffeine only.

Acetylcholine- and caffeine-induced responses in $\mathrm{Ca}^{2+}$-free external solution. To determine if the presence of external calcium was important in shaping the $\mathrm{Ca}^{2+}$ responses to acetylcholine and caffeine, experiments were performed on dendrites and somata in $\mathrm{Ca}^{2+}$-free and $\mathrm{Ca}^{2+}$-containing external solutions. Although experiments in $\mathrm{Ca}^{2+}$-free solutions were not performed in the presence of a calcium chelator, our previous results (Barish and Mansdorf, 1991) have shown that depolarizing hippocampal neurons in $\mathrm{Ca}^{2+}$-free solution using high $\mathrm{K}^{+}$ results in no change in $\left[\mathrm{Ca}^{2+}\right]_{i}$. In dendrites, the acetylcholineinduced $\mathrm{Ca}^{2+}$ response recorded in $\mathrm{Ca}^{2+}$-free external solution showed a transient time course similar in amplitude to, and the same duration as, the $\mathrm{Ca}^{2+}$ response in $\mathrm{Ca}^{2+}$-containing external solution (Fig. 9Aii). In four out of five experiments where the dendrite responded to both challenges of acetylcholine, the same response pattern was seen in the presence and absence of external $\mathrm{Ca}^{2+}$. Similarly, in four out of four experiments the caffeine-induced $\mathrm{Ca}^{2+}$ response in dendrites showed a sustained time course in the continuous presence of caffeine in both $\mathrm{Ca}^{2+}$-containing and $\mathrm{Ca}^{2+}$-free external solutions (Fig. 9Bii).

In somata, $\mathrm{Ca}^{2+}$ responses to both acetylcholine (Fig. 10A) and caffeine (Fig. 10B) were not significantly different when $\mathrm{Ca}^{2+}$ was not present during a first trial, but were slightly reduced when acetylcholine and caffeine were presented a second time in $\mathrm{Ca}^{2+}$-free external solution. When $\mathrm{Ca}^{2+}$ was returned to the perfusing solution, both acetylcholine- and caffeine-induced responses increased slightly. However, none of these differences proved to be statistically significant when the means were compared for acetylcholine $(n=30)$ and caffeine $(n=17)$.

These results suggest that influx of external $\mathrm{Ca}^{2+}$ does not play a significant role in shaping the $\mathrm{Ca}^{2+}$ responses to acetylcholine and caffeine in either dendrites or somata. It is interesting to note that the temporal pattern of $\mathrm{Ca}^{2+}$ release induced 
by caffeine in dendrites differs from that in somata in both $\mathrm{Ca}^{2+}$-free and $\mathrm{Ca}^{2+}$-containing external solutions.

Interaction of $\mathrm{Ca}^{2+}$ responses to acetylcholine and caffeine in somata. Examining the interactions of the $\mathrm{Ca}^{2+}$ release systems required acquisition of multiple responses that could not be obtained from dendrites using the LSM due to irreparable tissue damage. Therefore, we used video-based microscopy to study the interactions of $\mathrm{Ca}^{2+}$ responses in neuronal somata.

Figure $11 A$ illustrates partial occlusion of the $\mathrm{Ca}^{2+}$ response to acetylcholine by simultaneous exposure to caffeine. Caffeine significantly reduced the amplitude of the $\mathrm{Ca}^{2+}$ response to acetylcholine in 10 of 13 neurons that responded to both stimuli; there was no decrement in the other three cells. Preexposure to caffeine reduced the response to acetylcholine to approximately $7 \%$ of control $(7.3 \% \pm 2.6$, mean $\pm \mathrm{SEM}, n=$ 10). After washing, the $\mathrm{Ca}^{2+}$ response to acetylcholine returned to approximately $50 \%$ of the initial value $(48 \%+7)$ of the control value.

In the complementary experiment, partial occlusion of the $\mathrm{Ca}^{2+}$ response to caffeine by simultaneous exposure to acetylcholine was also observed (Fig. $11 B$ ). The $\mathrm{Ca}^{2+}$ response to caffeine was significantly reduced by acetylcholine in 21 of 23 neurons that responded to both stimuli; in the remaining two cells there was no decrement. Overall, in the presence of acetylcholine, the $\mathrm{Ca}^{2+}$ response to caffeine was reduced to about $21 \%$ of control value $(21 \% \pm 3, n=21)$. After washing the response to caffeine returned to about $60 \%$ of control $(64 \% \pm$ 8).

In control experiments on sister cultures, $\mathrm{Ca}^{2+}$ responses to acetylcholine and caffeine decremented to $50-55 \%$ of their initial value over threc test pulses (data not shown). We concluded, therefore, that the decrements in response amplitude produced by simultaneous application of two stimuli were not long lasting.

\section{Discussion}

\section{The distributions of $\operatorname{Ins} P_{3} R$ and $R y R$}

Our immunocytochemical data indicate that $\operatorname{Ins} \mathrm{P}_{3} \mathrm{R}$ and $\mathrm{RyR}$ coexist as intermixed aggregates in individual cultured hippocampal neurons. Clusters of $\operatorname{InsP}_{3} \mathrm{R}$ were more diffusely distributed than RyR, and were found in more distal processes, and thus the relative densities of $\mathrm{Ca}^{2+}$ release channels varied, with distal dendrites containing a higher proportion of Ins $P_{3} R$. Aggregations of InsP $\mathrm{R}$ and $\mathrm{RyR}$ have been previously observed (Walton et al., 1991; Sharp et al., 1993b), with Walton et al. (1991) reporting that RyR clusters were particularly punctate when compared with $\operatorname{InsP}_{3} \mathrm{R}$ distribution.

Previous studies have also indicated that the proportions of Ins $\mathrm{P}_{3} \mathrm{R}$ and $\mathrm{RyR}$ vary in different regions of individual neurons and between different types of neurons. For example, Sharp et al. (1993b) detected InsP $\mathrm{R}_{3} \mathrm{R}$ and RyR immunoreactivities in somata and dendrites, but only RyR immunoreactivity in dendritic spines of rat hippocampal slice neurons. In contrast, Walton et al. (1991) found both $\operatorname{InsP}_{3} R$ and $R y R$ in somata and dendritic shafts of cerebellar Purkinje neurons, but only $\operatorname{Ins}_{3} R$ immunoreactivity in dendritic spines.

Electron micrographs have shown that $\operatorname{Ins}_{3} \mathrm{R}$ and $\mathrm{RyR}$ coexist in varying proportions on the membranes of the rough and smooth ER, subsurface cisternae, and the nuclear envelope (Walton et al., 1991; Martone, 1993). Our observations indicate that signals related to the glia, on which the cultured hippocampal neurons are grown, may influence the distributions of
Ins $P_{3} R$ but not $R y R$. Since the tubules and cisternae in the dendritic shafts and spines of Purkinje neurons are highly contiguous (Martone et al., 1993), and one interpretation of our physiological data (see below) is that the $\operatorname{Ins}_{3} \mathrm{R}$ and $\mathrm{RyR}$ draw from a common $\mathrm{Ca}^{2+}$ pool, it is possible that, as with surface membranes, the interconnected internal ER membrane network shows regional specializations and domains that are regulated by presently unknown epigenetic mechanisms (Sitia and Meldolesi, 1992; Takei et al., 1992; Nori et al., 1993; Volpe et al., 1993).

\section{Intracellular $\mathrm{Ca}^{2+}$ responses to acetylcholine and caffeine}

Dendritic $\mathrm{Ca}^{2+}$ responses to acetylcholine and caffeine differed from those obtained from somata (for other observations on somata, see Kudo et al., 1988; Murphy and Miller, 1989; Tsai and Barish, 1990, 1991, unpublished observations; Uneyama et al., 1993). We ohserved that $\mathrm{Ca}^{2+}$ transients elicited by caffeine declined more slowly in dendrites than in somata, while responses to acetylcholine declined more rapidly in dendrites than in somata. The source(s) of these differences is not clear, but as they are preserved in the absence of external $\mathrm{Ca}^{2+}$ it suggests an intrinsic difference in the functioning of $\mathrm{Ca}^{2}$ release and regulating systems of somata and dendrites.

The spatial patterns of $\mathrm{Ca}^{2+}$ responses to acetylcholine and caffeine reflected the distributions of $\operatorname{InsP}_{3} \mathrm{R}$ and $\mathrm{RyR}$ within neurons. Thus, both $\mathrm{Ca}^{2+}$ responses to caffeine and RyR immunoreactivity were more prominent in proximal dendritic regions, while $\mathrm{Ca}^{2+}$ responses to acetylcholine and $\operatorname{InsP}_{3} \mathrm{R}$ immunoreactivity were distributed throughout dendritic processes. We observed that regions of $\mathrm{Ca}^{2+}$ responsiveness within a given ncuron were often localized to individual dendritic branchlets, possibly defining $\mathrm{Ca}^{2+}$ domains. These domains were larger than the individual aggregations of $\operatorname{InsP}_{3} \mathrm{R}$ or $\mathrm{RyR}$, which may indicate the presence of $\mathrm{Ca}^{2+}$ compartmentalization due to ER regionalization and/or nonuniform distributions of $\mathrm{Ca}^{2+}$-buffering proteins.

Propagating regenerative $\mathrm{Ca}^{2+}$ surges have previously been observed in large cells and cell networks, such as newly fertilized eggs (Gilkey et al., 1978; Busa and Nuccitelli, 1985; Miyazaki et al., 1986), cardiac myocytes (Takamatsu and Weir, 1990), muscarinic acetylcholine receptor mRNA-injected Xenopus oocytes (Lechleiter et al., 1991), and gap junction-coupled cultured glial or airway cells (Sanderson et al., 1988; Cornell-Bell et al., 1990; Charles et al., 1991; Dani et al., 1992), but their presence in neurons is unclear. In time series experiments we observed regions of high $\left[\mathrm{Ca}^{2+}\right]$ that moved along processes during stimulation by acetylcholine or caffeine. Unfortunately, because the apparent peak-to-peak interval of these waves (about $25 \mu \mathrm{m}$ ) was similar to the size of the field examined on the LSM, a $\mathrm{Ca}^{2+}$ peak could not be followed along the entire dendrite, and we could not determine if these regions of high $\left[\mathrm{Ca}^{2+}\right]$ migrated in an organized manner.

\section{Interactions of the intracellular stores}

We observed mutual inhibition of caffeine-induced $\mathrm{Ca}^{2+}$ release and acetylcholine-gated $\mathrm{Ca}^{2+}$ release in somata. This observation is similar to reports on chromaffin cells, in which $\left[\mathrm{Ca}^{2+}\right]_{i}$ transients induced by activation of caffeine-induced and angiotensin-gated $\mathrm{Ca}^{2+}$ release show different spatial distributions that correlate with the locations of different $\mathrm{Ca}^{2+}$ ATPases (Burgoyne et al., 1989), but show occlusion when methacholine-induced $\mathrm{Ca}^{2+}$ release is preceded by exposure to caffeine 

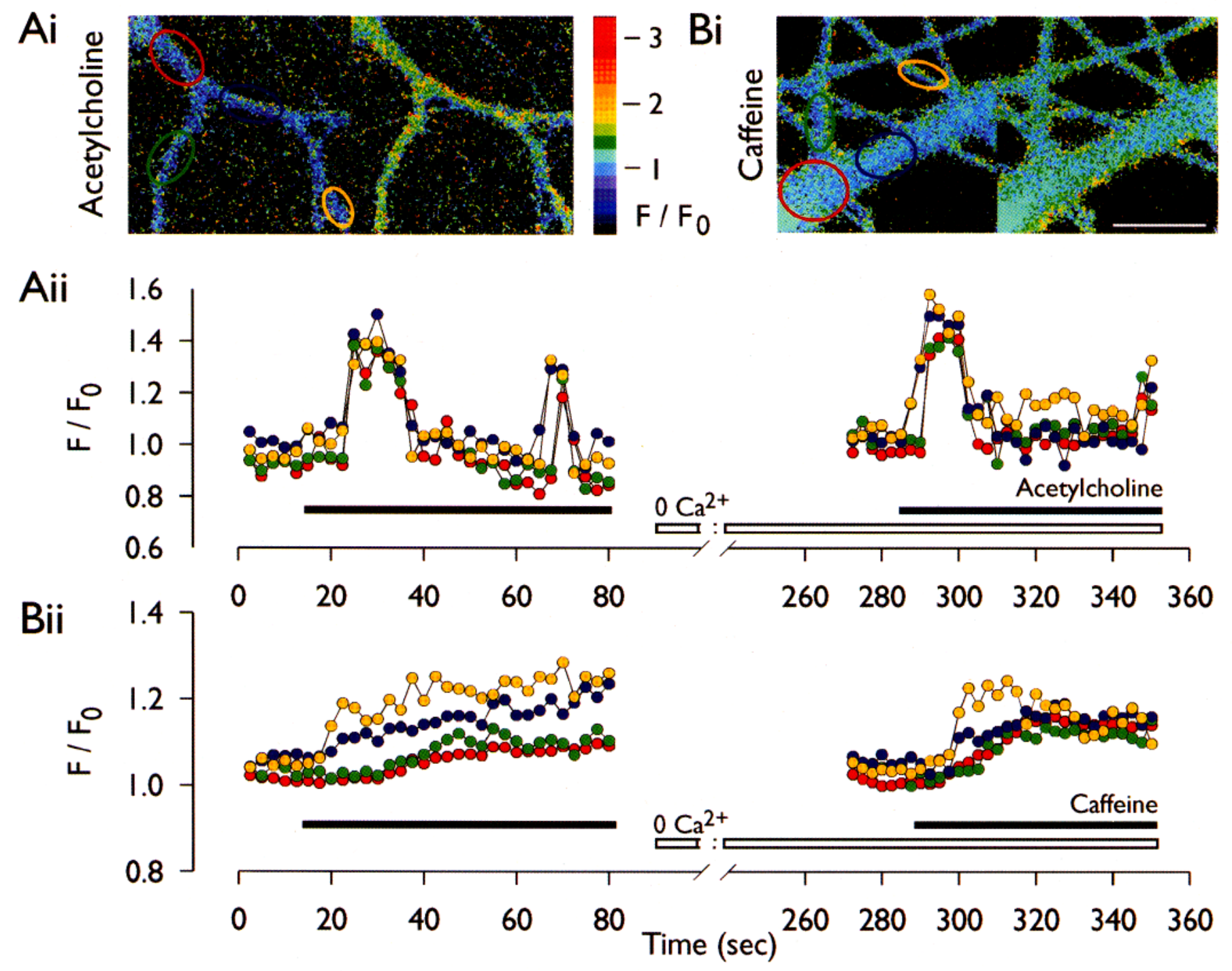

Figure 9. Acetylcholine- and caffeine-induced $\mathrm{Ca}^{2+}$ increases in dendrites are similar in $\mathrm{Ca}^{2+}$-containing and $\mathrm{Ca}^{2+}$-free external solutions. Ai and $\mathrm{Bi}$ are normalized $\left(F / F_{0}\right)$ fluorescence confocal microscope images collected at $2.56 \mathrm{sec}$ intervals demonstrating relative fluorescence changes in response to $10 \mu \mathrm{M}$ acetylcholine and $10 \mathrm{~mm}$ caffeine. The first image in each pair shows the normalized fluorescence ratio at rest, and the second shows the peak response. The proximal region of the dendrite is toward the top of $A i$ and the bottom of the $B i$ image. Data collection, analysis, and presentation are as described for Figure 5. The pseudocolor bar indicates the colors representing the normalized fluorescence values. Scale bar, $20 \mu \mathrm{m}$. Aii is average relative fluorescence values in the four regions indicated in the resting image in $\mathrm{A} i$ in response to acetylcholine in Ca ${ }^{2+}-$ containing and $\mathrm{Ca}^{2}$-free external solutions plotted against time. The acetylcholine-induced $\mathrm{Ca}^{2+}$ increase was transient in both the presence and absence of external calcium. Acetylcholine was applied continuously from the end of the fifth frame collection to the end of the $32 \mathrm{nd}$ frame as indicated by the solid black bar on the plots. The dendrite was washed for $3 \mathrm{~min}$ in $\mathrm{Ca}^{2+}$-free external solution, as indicated by the hollow bar, before the second acetylcholine trial. Bii, Average relative fluorescence values in the four regions indicated in $B i$ in response to caffeine as indicated by the solid bar. The dendrite was washed for $3 \mathrm{~min}$ in $\mathrm{Ca}^{2+}$-free external solution, as indicated by the hollow bar, before the second caffeine trial. The caffeine-induced $\mathrm{Ca}^{2+}$ response was more sustained than the acetylcholine-induced response in both $\mathrm{Ca}^{2+}$-containing and $\mathrm{Ca}^{2}$-free external solutions.

(Liu et al., 1991). Cultured cerebellar neurons also show mutually inhibiting interactions between caffeine-induced and acetylcholine-gated $\mathrm{Ca}^{2+}$ release processes that are similar to those reported here (Irving et al., 1992). In contrast, other investigations have suggested that the two $\mathrm{Ca}^{2+}$ release systems function relatively independently (Murphy and Miller, 1989, for cultured hippocampal neurons; Thayer et al., 1988, for sensory neurons). The reasons for these variations are not clear at present, but could be related to differences in cell type, species, or culture conditions.

The mechanisms by which the two release processes may interact are also not understood. The membrane systems on which the two receptors reside may be contiguous, and thus the $\mathrm{Ca}^{2+}$ release channels may draw on a common $\mathrm{Ca}^{2+}$ pool. Alternatively, the two mechanisms may act on separate $\mathrm{Ca}^{2+}$ pools but influence each other at the receptor level. For example, InsP $\mathrm{P}_{3}$-gated channels might release $\mathrm{Ca}^{2+}$ which would in turn induce $\mathrm{Ca}^{2+}$ release from the $\mathrm{Ca}^{2+}$-induced calcium release pathway through ryanodine receptors (Berridge, 1991; Reber et al., 1993). Caffeine in turn might influence activation of the $\mathrm{InsP}_{3}$-gated $\mathrm{Ca}^{2+}$ release channel (1) by increasing cytosolic $\mathrm{Ca}^{2+}$, and thus reducing $\mathrm{InsP}_{3}$ binding to its receptor 

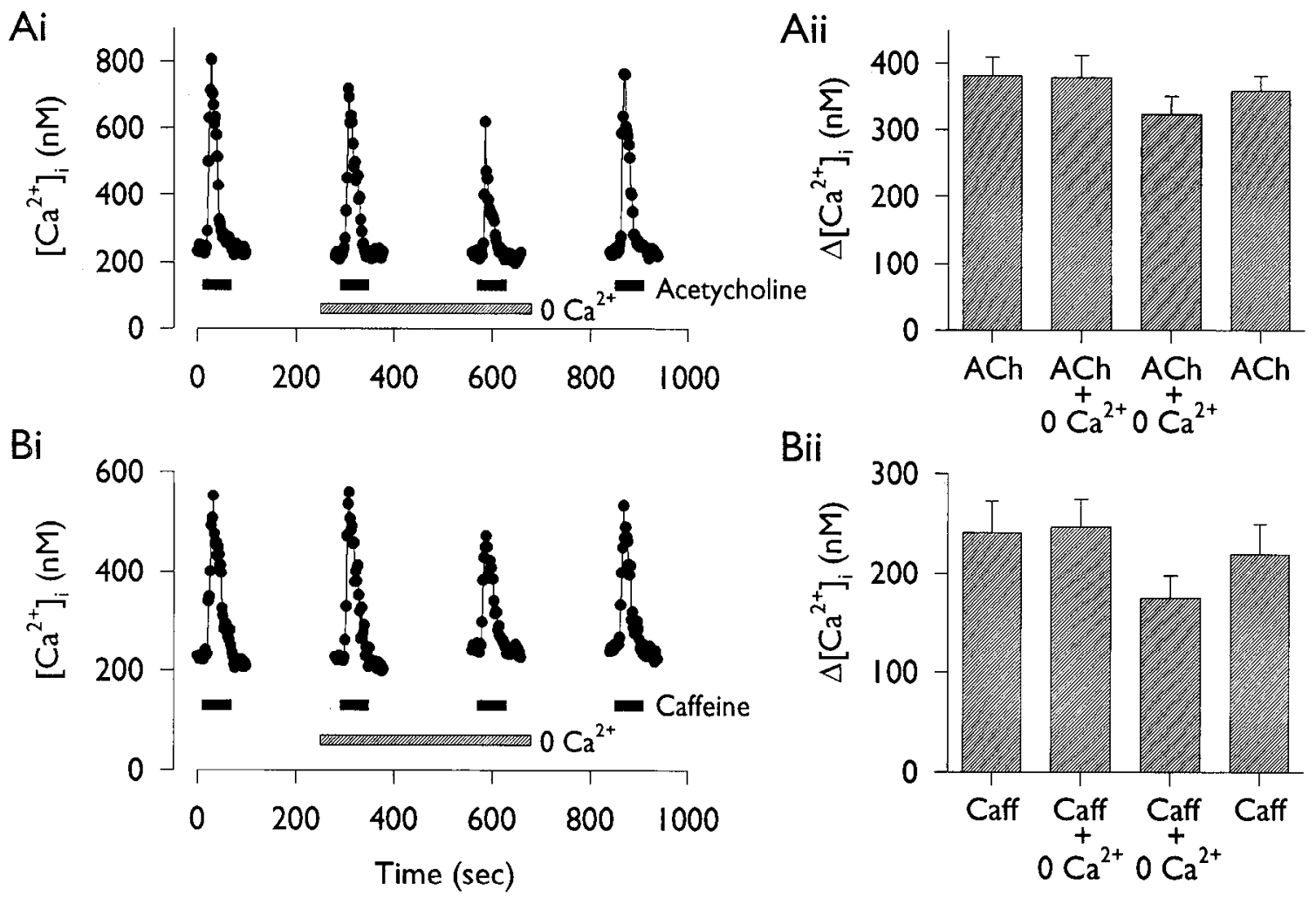

Figure 10. Acetylcholine- and caffeine-induced $\mathrm{Ca}^{2+}$ increases in somata are the same in $\mathrm{Ca}^{2+}$-containing and $\mathrm{Ca}^{2+}-$ free external solutions. $\mathrm{Ai}$ is

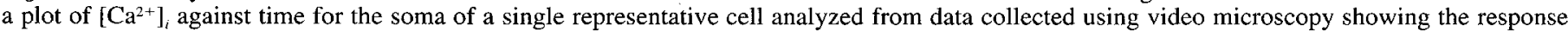
to acetylcholine $(10 \mu \mathrm{M})$ (solid bar) in the presence and absence of external $\mathrm{Ca}^{2+}$. Application of $\mathrm{Ca}^{2+}$-free external solution is indicated by the patterned bar and $\mathrm{Ca}^{2+}$ responses to acetylcholine were slightly smaller in the absence of external $\mathrm{Ca}^{2+}$, with the second response being smaller than the first. $B i$, Plot of $\left[\mathrm{Ca}^{2+}\right]_{i}$ against time for the soma of a single representative cell showing the response to caffeine (10 mM) (solid bar). The response to caffeine was slightly reduced in the absence of external $\mathrm{Ca}^{2+}$, particularly the second response. Note that the caffeine response in the soma is transient and similar to the acetylcholine-induced response, not sustained like the caffeine response in the dendrites described in Figures 6, 7, and 9. Aii and Bii are bar plots of $\Delta\left[\mathrm{Ca}^{2+}\right]_{i}$ (the difference between peak and resting values) for each exposure to acetylcholine and caffeine. Data are mean $\pm \operatorname{SEM}(n=30$ for $A i ; n=17$ for $B i)$. Comparison of the means was performed using Student's $t$ test with the criterion for significance at $p<0.05$. When compared, none of the means in $\mathrm{Ca}^{2+}$-free solutions were significantly lower (all $p>0.05$ ) than the controls.

(Supattapone et al., 1988), (2) by sensitizing release at low resting $\left[\mathrm{Ca}^{2+}\right]_{i}$ by InsP $\mathrm{P}_{3}$ resident in the cytosol before application of acetylcholine (Bezprozvanny et al., 1991; Finch et al., 1991 ), or (3) by raising $\left[\mathrm{Ca}^{2+}\right]_{i}$ sufficiently to reduce $\mathrm{InsP}_{3}$ gated $\mathrm{Ca}^{2+}$ release (Bezprozvanny et al., 1991). Caffeine may also directly interfere with $\mathrm{InsP}_{3} \mathrm{R}$ activation (Parker and Ivorra, 1990).

The interactions between acetylcholine- and caffeine-induced $\mathrm{Ca}^{2+}$ release suggest the operation of a two-pool oscillator such as that described for other systems (Berridge, 1990, 1991, 1992). However, in general the mechanisms of $\mathrm{Ca}^{2+}$ wave oscillation and propagation differ between cells and systems (Berridge and Galione, 1988; Harootunian et al., 1991; Tsunoda, 1991), and it remains to be determined which are present in hippocampal neurons.

\section{Physiological significance of different spatial and temporal patterns of calcium release}

The physiological role of intracellular signals mediated by RyR or InsP $\mathrm{P}_{3} \mathrm{R}$ is not well understood, but changes in $\mathrm{Ca}^{2+}$ play an important role in many neuronal events (Kennedy, 1989; Miller, 1991; Henzi and MacDermott, 1992). The release of $\mathrm{Ca}^{2+}$ from intracellular stores can influence the signaling properties of neurons in two general ways: (1) by altering the action po- tential waveform and thus the excitability of a neuron, and (2) by amplifying $\mathrm{Ca}^{2+}$ signals in a localized region. Release of $\mathrm{Ca}^{2+}$ from intracellular stores has been shown to influence $\mathrm{Ca}^{2+}$-activated $\mathrm{K}^{+}$currents and thus slow after-hyperpolarizations in cerebellar Purkinje (Brorson et al., 1991) and peripheral (Kuba et al., 1983; Kawai and Watanabe, 1989; Sah and McLachlan, 1991) neurons. Since some after-hyperpolarizations have been linked to activation of $\mathrm{Ca}^{2+}$-induced $\mathrm{Ca}^{2+}$ release, localization of RyR to specific dendrites may indicate spatially distributed modulation of the action potential waveform.

Localized changes in $\left[\mathrm{Ca}^{2+}\right]_{i}$ may also shape and partition cellular processes. Hippocampal neurons can restrict the diffusion of $\mathrm{Ca}^{2+}$ between dendrites and spines (Guthrie et al., 1991; Müller and Conner, 1991). Although the restriction mechanisms are not known, one could involve the RyR localized in spines (Sharp et al., 1993b) that may function to rapidly amplify highly localized increases in $\left[\mathrm{Ca}^{2+}\right]_{i}$ (Miller, 1992; Alford et al., 1993). This could operate during synaptic input onto dendritic spines, as single spines can accumulate $\mathrm{Ca}^{2+}$ during stimulation (Andrews et al., 1988) and $\left[\mathrm{Ca}^{2+}\right]_{i}$ responses to synaptic input on glutamate receptor activation can be attenuated by manipulation of $\mathrm{Ca}^{2+}$-induced $\mathrm{Ca}^{2+}$ release (Mody et al., 1991; Alford et al., 1993). Spatial restriction of $\mathrm{Ca}^{2+}$ signals 

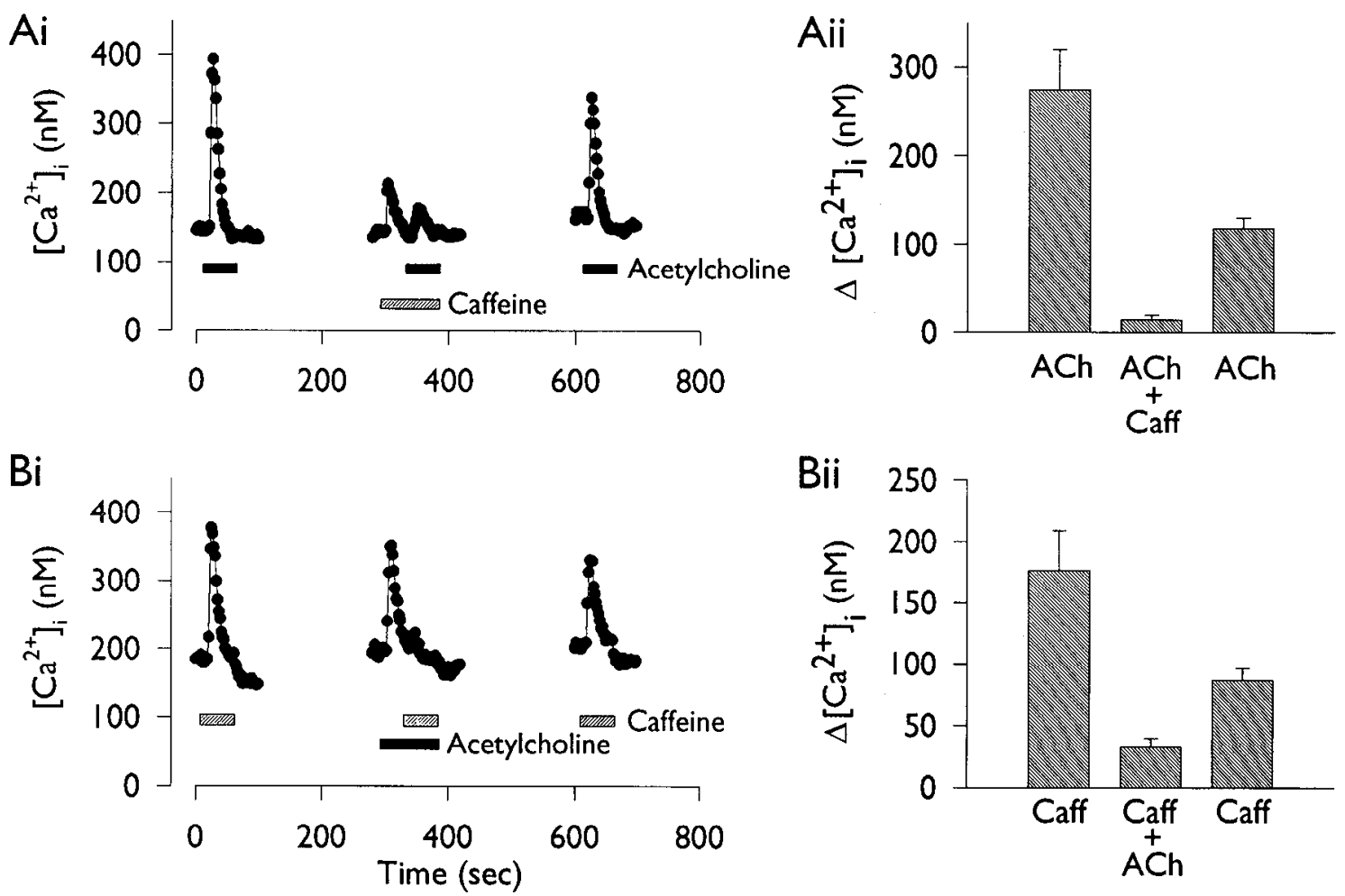

Figure 11. Interactions between caffeine- and acetylcholine-induced $\mathrm{Ca}^{2+}$ release. $\mathrm{Ai}$ is a plot of $\left[\mathrm{Ca}^{2+}\right]_{i}$ against time for the soma of a single representative cell analyzed from data collected using video microscopy showing the suppression of responses to acetylcholine (10 $\mu \mathrm{M}$ for 40 sec) during simultaneous application of caffeine $(10 \mathrm{mM}$ for $80 \mathrm{sec})$. The response to acetylcholine was reduced to $21 \%$ of its initial value in the presence of caffeine. The applications of caffeine and acetylcholine are indicated by patterned bars in the plot. Bi Plot of [Ca $\left.{ }^{2+}\right]_{i}$ against time for the soma of a single representative cell showing the suppression of responses to caffeine (10 mM for $40 \mathrm{sec})$ during application of acetylcholine (10 $\mu \mathrm{M}$ for $80 \mathrm{sec}$ ). The response to caffeine was reduced to $15 \%$ of its initial value in the presence of acetylcholine. 'l'he ability of caffeine to reduce resting $\left[\mathrm{Ca}^{2+}\right]_{i}$ to below its initial value has been previously described (Tsai and Barish, unpublished observations). Aii and Bii are bar plots of $\Delta\left[\mathrm{Ca}^{2+}\right]_{i}$ (the difference between peak and resting values) before, during, and after simultaneous application of stimuli. Data are mean \pm SEM ( $n=10$ for $A i ; n=21$ for $B i$ ). Comparison of the means was performed using Student's $t$ test with the criterion for significance at $p<0.05$. In each case the middle response is significantly lower ( $p<0.05$ or smaller) than either the first or recovery trials. There was no statistically significant difference between the response decrement between the first and third trials in cells exposed to caffeine or acetylcholine alone (not shown) and the experimental cells (Aii, Bii) $(p>0.8)$.

may be related to the pathway specificity of hippocampal longterm synaptic potentiation (LTP), during which $\mathrm{Ca}^{2+}$-dependent postsynaptic reactions to synapse activation are limited to single inputs (Madison et al., 1991).

In general, spatial limitation of $\mathrm{Ca}^{2+}$ responsiveness may contribute to independent processing of synaptic input by regions of the dendritic tree, while at the same time permitting integration of activity across the entire neuron.

\section{References}

Alford S, Frenguelli BG, Schofield JG, Collingridge GL (1993) Characterization of $\mathrm{Ca}^{2+}$ signals induced in hippocampal CA1 neurones by the synaptic activation of NMDA receptors. J Physiol (Lond) 469:693-716.

Andrews SB, Leapman RD, Landis DMD, Reese TS (1988) Activitydependent accumulations of calcium in Purkinje cell dendritic spines. Proc Natl Acad Sci USA 85:1682-1685.

Banker GA, Cowan WM (1977) Rat hippocampal neurons in dispersed cell culture. Brain Res 126:397-425.

Banker GA, Cowan WM (1979) Further observations on hippocampal neurons in dispersed cell culture. J Comp Neurol 187:469-494.

Barish ME, Mansdorf NB (1991) Development of intracellular calcium responses to depolarization and to kainate and $N$-methyl-Daspartate in cultured mouse hippocampal neurons. Dev Brain Res 63:53-61.

Berridge MJ (1990) Calcium oscillations. J Biol Chem 265:95839586 .
Berridge MJ (1991) Cytoplasmic calcium oscillations: a two pool model. Cell Calcium 12:63-72.

Berridge MJ (1992) Spatiotemporal aspects of calcium signalling. Jpn J Pharmacol 58[Suppl 2]:142P-149P.

Berridge MI, Galione A (1988) Cytosolic calcium oscillators. FASER J 2:3074-3082.

Berridge MJ, Taylor CW (1988) Inositol trisphosphate and calcium signalling. Cold Spring Harbor Symp Quant Biol 53:927-933.

Berridge MJ, Dawson RMC, Downes CP, Heslop JP, Irvine RF (1983) Changes in the levels of inositol phosphates after agonist-dependent hydrolysis of membrane phosphoinositides. Biochem J 212:473482.

Bezprozvanny I, Watras J, Ehrlich BE (1991) Bell-shaped calciumresponse curves of Ins $(1,4,5) \mathrm{P}_{3}$ - and calcium-gated channels from endoplasmic reticulum of cerebellum. Nature 351:751-754.

Blaustein MP (1988) Calcium transport and buffering in neurons. Trends Neurosci 11:438-443.

Brorson JR, Bleakman D, Gibbons SJ, Miller RJ (1991) The properties of intracellular calcium stores in cultured rat cerebellar neurons. J Neurosci 11:4024-4043.

Buck WR, Hoffman EE, Rakow TL, Shen SS (1994) Synergistic calcium release in the sea urchin egg by ryanodine and cyclic ADPribose. Dev Biol 163:1-10.

Burgoyne RD, Cheek TR, Morgan A, O'Sullivan AJ, Moreton RB, Berridge MJ, Mata AM, Colyer J, Lee AG, East JM (1989) Distribution of two distinct $\mathrm{Ca}^{2+}$-ATPase-like proteins and their relationships to the agonist-sensitive calcium store in adrenal chromaffin cells. Nature 342:72-74.

Busa WB, Nuccitelli R (1985) An elevated free $\mathrm{Ca}^{2+}$ wave follows 
fertilization in eggs of the frog, Xenopus laevis. I Cell Biol 100: $1325-1329$.

Charles AC, Merrill JE, Dirksen ER, Sanderson MJ (1991) Intercellular signalling in glial cells: calcium waves and oscillations in re sponse to mechanical stimulation and glutamate. Neuron 6:983992.

Cornell-Bell AH, Finkbeiner SM, Cooper M, Smith SJ (1990) Glutamate induced calcium waves in cultured astrocytes: long-range glial signaling. Science 247:470-473.

Dani JW, Chernjavsky A, Smith SJ (1992) Neuronal activity triggers calcium waves in hippocampal astrocyte networks. Neuron 8:429440

Dotti C, Sullivan C, Banker G (1988) The establishment of polarity by hippocampal neurons in culture. $J$ Neurosci 8:1454-1468.

Ellisman MH, Deerinck TJ, Ouyang Y, Beck CF, Tanksley SJ, Walton PD, Airey JA, Sutko JL (1990) Identification and localization of ryanodine binding proteins in the avian central nervous system. Neuron 5:135-146.

Finch EA, Turner TJ, Goldin SM (1991) Calcium as coagonist of inositol 1,4,5-trisphosphate-induced calcium release. Science 352: $443-446$.

Furuichi T, Yoshikawa S, Miyawaki A, Wada K, Maeda N, Mikoshiba $\mathrm{K}$ (1989) Primary structure and functional expression of the inositol 1,4,5-trisphosphate-binding protein $\mathrm{P}_{400}$. Nature 342:32-38.

Gilkey JC, Jaffe LF, Ridgway EB, Reynolds GT (1978) A free calcium wave traverses the activating egg of the medaka Oryzias latipes. J Cell Biol 76:448-466.

Grynkiewicz G, Poenie M, Tsien RY (1985) A new generation of $\mathrm{Ca}^{2+}$ indicators with greatly improved fluorescence properties. J Biol Chem 260:3440-3450.

Guthrie PB, Segal M, Kater SB (1991) Independent regulation of calcium revealed by imaging dendritic spines. Nature 354:76-80.

Harootunian AT, Kao JPY, Paranjape S, Tsien RY (1991) Generation of calcium oscillations in fibroblasts by positive feedback between calcium and $\mathrm{IP}_{3}$. Science 251:75-78.

Henzi V, MacDermott AB (1992) Characteristics and function of $\mathrm{Ca}^{2+}$ - and inositol 1,4,5-trisphosphate-releasable stores of $\mathrm{Ca}^{2+}$ in neurons. Neuroscience 46:251-273.

Irving AJ, Collingridge GL, Schofield JG (1992) Interactions between $\mathrm{Ca}^{2+}$ mobilizing mechanisms in cultured rat cerebellar cells. J Physiol (Lond) 456:667-680.

Kawai T, Watanabe M (1989) Effects of ryanodine on the spike afterhyperpolarization in sympathetic neurones of the rat superior cervical ganglion. Pfluegers Arch 413:470-475.

Kennedy MB (1989) Regulation of neuronal function by calcium. Trends Neurosci 12:417-420.

Kreigstein AR, Dichter MA (1983) Morphological classification of rat cortical neurons in cell culture. J Neurosci 3:1634-1647.

Kuba K, Morita K, Nohmi M (1983) Origin of calcium ions involved in the generation of a slow afterhyperpolarization in bullfrog sympathetic neurons. Pfluegers Arch 399:194-202

Kudo Y, Ogura A, Iijima T (1988) Stimulation of muscarinic receptor in hippocampal neuron induces characteristic increase in cytosolic free $\mathrm{Ca}^{2+}$ concentration. Neurosci Lett 85:345-350.

Lechleiter J, Girard S, Peralta E, Clapham D (1991) Spiral calcium wave propagation and annihilation in Xenopus laevis oocytes. Science 252:123-126.

Levey AI (1993) Immunological localization of $\mathrm{m} 1-\mathrm{m} 5$ muscarinic acetylcholine receptors in peripheral tissues and brain. Life Sci 52 441-448.

Levey AI, Kitt CA, Simonds WF Price DL, Brann MR (1991) Identification and localization of muscarinic acetylcholine receptor proteins in brain with subtype-specific antibodies. J Neurosci 11:32183226 .

Liu P-S, Lin Y-J, Kao L-S (1991) Caffeine-sensitive calcium stores in bovine adrenal chromaffin cells. J Neurochem 56:172-177.

Madison DV, Malenka RC, Nicoll RA (1991) Mechanisms underlying long-term potentiation of synaptic transmission. Annu Rev Neurosci $14: 379-397$

Martone ME, Zhang Y, Simpliciano VM, Carragher BO, Ellisman MH (1993) Three-dimensional visualization of the smooth endoplasmic reticulum in Purkinje cell dendrites. J Neurosci 11:4636-4646.

Mignery GA, Südhof TC, Takei K, De Camilli P (1989) Putative receptor for inositol 1,4,5-trisphosphate similar to ryanodine receptor. Nature 342:192-195.
Miller RI (1991) The control of neuronal $\mathrm{Ca}^{2+}$ homeostasis. Prog Neurobiol 37:255-285.

Miller RJ (1992) Neuronal $\mathrm{Ca}^{2+}$ : getting it up and keeping it up. Trends Neurosci 15:317-319.

Miyazaki S-I, Hashimoto N, Yoshimoto Y, Kishimoto T, Igusa Y, Hiramoto $Y$ (1986) Temporal and spatial dynamics of the periodic increase in intracellular free calcium at fertilization of golden hamster eggs. Dev Biol 118:259-267.

Mody I, Baimbridge KG, Shacklock JA, MacDonald JF (1991) Release of intracellularly stored $\mathrm{Ca}^{2+}$ in hippocampal neurons by NMDA receptor activation. Exp Brain Res 20:75-80.

Müller W, Connor JA (1991) Dendritic spines as individual neuronal compartments for synaptic $\mathrm{Ca}^{2+}$ responses. Nature 354:73-76.

Murphy SN, Miller RJ (1989) Two distinct quisqualate receptors regulate $\mathrm{Ca}^{2+}$ homeostasis in hippocampal neurons in vitro. Mol Pharmacol 35:671-680.

Nakanishi S, Maeda N, Mikoshiba K (1991) Immunohistochemical localization of an inositol 1,4,5-trisphosphate receptor, $P_{400}$, in neural tissue: studies in developing and adult mouse brain. J Neurosci 11:2075-2086.

Nori A, Villa A, Podini P, Witcher DR, Volpe P (1993) Intracellular $\mathrm{Ca}^{2+}$ stores of rat cerebellum: heterogeneity within and distinction from endoplasmic reticulum. Biochem J 291:199-204.

Padua RA, Wan W, Nagy Jl, Geiger JD (1991) [ $\left.{ }^{3} \mathrm{H}\right]$ Ryanodine binding sites in rat brain demonstrated by membrane binding and autoradiography. Brain Res 542:135-140.

Parker I, Ivorra I (1990) Inhibition by $\mathrm{Ca}^{2+}$ of inositol trisphosphatemediated $\mathrm{Ca}^{2+}$ liberation: a possible mechanism for oscillatory release of $\mathrm{Ca}^{2+}$. Proc Natl Acad Sci USA 87:260-264.

Reber BFX, Stuki JW, Reuter H (1993) Unidirectional interaction between two intracellular calcium stores in rat phaeochromosytoma (PC12) cells. J Physiol (Lond) 468:711-727.

Ross CA, Meldolesi J, Milner TA, Satoh T, Supattapone S, Snyder SH (1989) Inositol 1,4,5-trisphosphate receptor localized to endoplasmic reticulum in cerebellar Purkinje neurons. Nature 339:468-470.

Sah P, McLachlan EM (1991) $\mathrm{Ca}^{2+}$-activated $\mathrm{K}^{+}$currents underlying the afterhyperpolarization in guinea pig vagal neurons: a role for $\mathrm{Ca}^{2+}$-activated $\mathrm{Ca}^{2+}$ release. Neuron 7:257-264.

Sah P, Francis K, McLachlan EM, Junakar P (1993) Distribution of ryanodine receptor-like immunoreactivity in mammalian central nervous system is consistent with its role in calcium-induced calcium release. Neuroscience 54:157-165.

Sanderson MJ, Chow I, Dirksen ER (1988) Intercellular communication between ciliated cells in culture. Am J Physiol 254:C63-C74.

Sharp AH, Dawson TM, Ross CA, Fotuhi M, Mourey RJ, Snyder SH (1993a) Inositol 1,4,5-trisphosphate receptors: immunohistochemical localization to discrete areas of rat central nervous system. Neuroscience 53:927-942.

Sharp AH, McPherson PS, Dawson TM, Aoki C, Campbell KP, Snyder SH (1993b) Differential immunohistochemical localization of inositol 1,4,5-trisphosphate- and ryanodine-sensitive $\mathrm{Ca}^{2+}$ release channels in rat brain. J Neurosci 13:3051-3063.

Sitia R, Meldolesi J (1992) Endoplasmic reticulum: a dynamic patchwork of specialized subregions. Mol Biol Cell 3:1067-1072.

Supattapone S, Worly PF, Baraban JM, Snyder SH (1988) Solubilization, purification and characterization of an inositol trisphosphate receptor. J Biol Chem 263:1530-1534.

Takamatsu T, Weir WG (1990) Calcium waves in mammalian heart: quantification of origin, magnitude, waveform, and velocity. FASEB J 4:1519-1525.

Takei K, Stukenbrok H, Metcalf A, Mignery GA, Südhof TC, Volpe P, De Camilli P (1992) $\mathrm{Ca}^{2+}$ stores in Purkinje neurons: endoplasmic reticulum subcompartments demonstrated by the heterogeneous distribution of the $\mathrm{InsP}_{3}$ receptor, $\mathrm{Ca}^{2+}$-ATPase, and calsequestrin. J Neurosci 12:489-505.

Thayer SA, Perney TM, Miller RJ (1988) Regulation of calcium homeostasis in sensory neurons by bradykinin. J Neurosci 8:4089. 4097.

Tsai TD, Barish ME (1990) Ryanodine sensitivity of caffeine-induced intracellular calcium release in cultured embryonic mouse cortical neurons. Biophys J 59:599a.

Tsai TD, Barish ME (1991) Caffeine-induced release of intracellular calcium ions in cultured embryonic mouse cortical neurons. Biomed Res 12[Suppl 2]:131-132. 
Tsien RW, Tsien RY (1990) Calcium channels, stores, and oscillations. Annu Rev Cell Biol 6:715-760.

Tsunoda Y (1991) Oscillatory $\mathrm{Ca}^{2+}$ signaling and its cellular function. New Biologist 3:3-17.

Uneyama H, Munakata M, Akaike N (1993) Caffeine response in pyramidal neurons freshly dissociated from rat hippocampus. Brain Res 604:24-31.

Villa A, Sharp AH, Raccetti G, Podini P, Bole DG, Dunn WA, Pozzan T, Snyder SH, Meldolesi J (1992) The endoplasmic reticulum of Purkinje neuron body and dendrites: molecular identity and specializations for $\mathrm{Ca}^{2+}$ transport. Neuroscience 49:467-477.

Volpe P, Villa A, Damiani E, Sharp AH, Podini P, Suyder SH, Melsolesi J (1991) Heterogeneity of microsomal $\mathrm{Ca}^{2+}$ stores in chicken Purkinje neurons. EMBO J 10:3183-3189.
Volpe P, Nori A, Martini A, Sacchetto R, Villa A (1993) Multiple/ heterogeneous $\mathrm{Ca}^{2+}$ stores in cerebellum Purkinje neurons. Comp Biochem Physiol 105A:205-211.

Walton PD, Airey JA, Sutko JL, Beck CF, Mignery GA, Südhof TC, Deerinck TJ, Ellisman MH (1991) Ryanodine and inositol trisphosphate receptors coexist in avian cerebellar Purkinje neurons. J Cell Biol 113:1145-1157.

White AM, Watson SP, Galione A (1993) Cyclic ADP-ribose-induced $\mathrm{Ca}^{2+}$ release from rat brain microsomcs. FEBS Lett 318:259-263.

Wu R-L, Barish ME (1992) Two pharmacologically and kinetically distinct transient potassium currents in cultured embryonic mouse hippocampal neurons. J Neurosci 12:2235-2246. 